\title{
Antibody-drug conjugates for the treatment of lymphoma: clinical advances and latest progress
}

Yurou Chu' ${ }^{1}$, Xiangxiang Zhou ${ }^{1,2,3,4,5,6^{*}}$ (1) and Xin Wang $1,2,3,4,5,6^{*}$

\begin{abstract}
Antibody-drug conjugates (ADCs) are a promising class of immunotherapies with the potential to specifically target tumor cells and ameliorate the therapeutic index of cytotoxic drugs. ADCs comprise monoclonal antibodies, cytotoxic payloads with inherent antitumor activity, and specialized linkers connecting the two. In recent years, three ADCs, brentuximab vedotin, polatuzumab vedotin, and loncastuximab tesirine, have been approved and are already establishing their place in lymphoma treatment. As the efficacy and safety of ADCs have moved in synchrony with advances in their design, a plethora of novel ADCs have garnered growing interest as treatments. In this review, we provide an overview of the essential elements of ADC strategies in lymphoma and elucidate the up-to-date progress, current challenges, and novel targets of ADCs in this rapidly evolving field.
\end{abstract}

Keywords: Antibody-drug conjugates, Lymphoma, Immunotherapy, Clinical trials

\section{Introduction}

Chemotherapy represents an essential pillar for the treatment of various forms of hematological malignancies. However, a common theme emerges where these chemotherapy agents are usually associated with nonspecific toxicities and increasing drug resistance, presumably because of their high potency but low tumor selectivity. In this respect, monoclonal antibodies (mAbs) such as rituximab and obinutuzumab designed to specifically bind an antigen on a cancerous cell have been proven to play an essential role in lymphoma treatment [1-4]. With the development of mAb technologies, antibodydrug conjugates (ADCs), comprising a mAb connected to a small molecule cytotoxic payload via a covalent linker (Fig. 1), have emerged as a novel class of promising immunotherapies in lymphoma.

\footnotetext{
*Correspondence: zhouxiangxiang90@163.com; xinw007@126.com ${ }^{1}$ Department of Hematology, Shandong Provincial Hospital, Cheeloo College of Medicine, Shandong University, No.324, Jingwu Road, Jinan 250021, Shandong, China

Full list of author information is available at the end of the article
}

Once attached to the corresponding cell-surface antigen of cancer cells, the ADC is internalized, and the cytotoxic payload is released, causing cell cycle termination and cell apoptosis. The drug can also diffuse into adjacent cells even if the cells are target-negative, resulting in cell death termed "bystander killing" (Fig. 2). This effect is generally believed to occur following the process of surface antigen targeting and internalization, but it was recently suggested to occur independently of internalization [5]. Despite the relatively straightforward molecular platform of ADCs, their application in clinical practice is hampered by multiple factors, including the narrow therapeutic index, the selection of the corresponding antibodies, the stability of the linkers, and the internalization rate of the payloads [6]. Hence, the generation of an efficacious and highly stable ADC is dependent on the proper arrangement of all sections.

At present, three ADCs, brentuximab vedotin (BV), polatuzumab vedotin (Pola), and loncastuximab tesirine, have been approved by the Food and Drug Administration (FDA) for various types of lymphoma, and these 


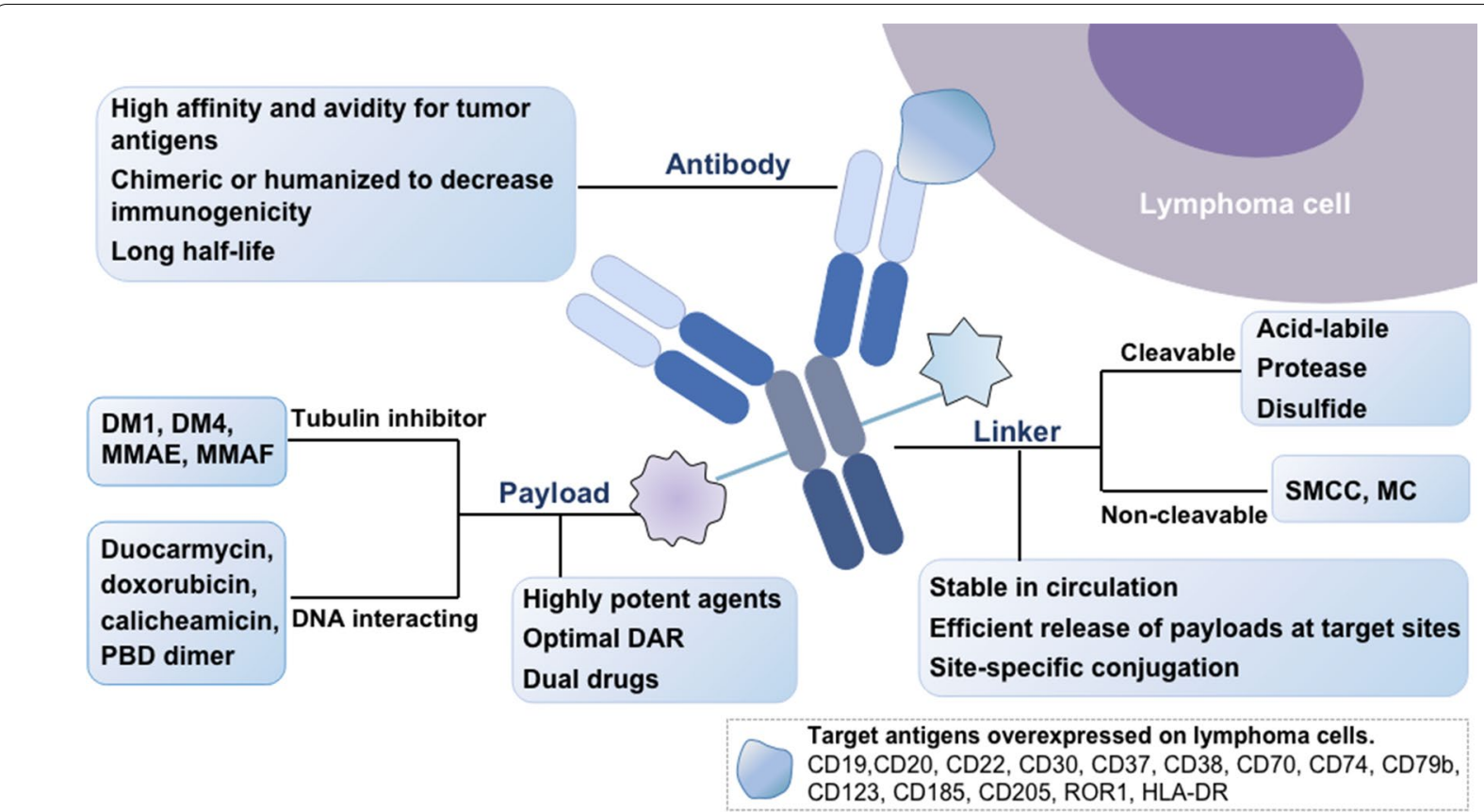

Fig. 1 Structure and properties of an antibody-drug conjugate. MMAE: monomethyl auristatin E; MMAF: monomethyl auristatin F; DM1: N20-deac etyl-N20-(3-mercapto-1-oxopropyl)-maytansine; DM4: N20-deacetyl-N20-(4-mercapto-4-methyl-1-oxopentyl)-maytansine; MC: maleimidocaproyl; SMCC: succinimidyl-4-(N-maleimidomethyl)-cyclohexane-1-carboxylate; PBD: pyrrolobenzodiazepines

agents exert favorable effects in clinical applications [7-10]. Furthermore, additional ADCs are presently in clinical trials to evaluate whether they can be efficacious treatment options for patients in diverse clinical settings. The topics discussed here involve the fundamental components of ADC strategies and focus on exploring opportunities for previously incurable subjects and summarizing the ADCs currently in clinical use and development (Table 1).

\section{Engineering ADCs}

\section{Antigens and corresponding antibodies}

Theoretically, an ideal antigen is broadly and homogeneously expressed on malignant cells and hardly present on normal cells, thereby maximizing efficacy and minimizing systemic toxicity. In most cases, ADCs are taken up by selective internalization via receptor-mediated endocytosis and yield intracellular cytotoxicity. The expression of homogeneous target antigens is not absolutely required for $\mathrm{ADC}$ efficiency, as heterogeneous tumors may benefit from bystander killing, which can affect proximally located antigen-negative tumor cells [11]. The effectiveness of the ADC-mediated bystander effect mostly relies on factors such as the extent of ADC internalization, the type of linkers, and the physicochemical properties of the attached payloads [5].
Antibodies used for ADCs for lymphoma are made to be chimeric, humanized, or fully human to generate the best immunogenicity profile. Owing to its favorable stability, immunoglobulin G (IgG) is the predominant class used in ADCs, and IgG1 represents a major subtype in the clinic [12]. IgG can induce antibody-dependent cellmediated cytotoxicity (ADCC), activation of antibodydependent cell-mediated phagocytosis (ADCP), and the complement pathway by triggering Fc $\gamma$ R-expressing cells [13]. Nevertheless, the strong induction of these effects may maximize tumor uptake at the expense of unacceptable systemic toxicity. The IgG4 isotype and Fc-mutated variants of the IgG1 isotype are designed to attenuate toxicity [14]. Non-IgG binding proteins may be a substitute that can be tailored for individual applications with varying degrees of stability and optimized efficacy [15, 16]. The IgM type has also been considered in development because of its greater number of engineered functional sites and higher drug-antibody ratio (DAR) [17]. In addition, triple variable domain Fab, with a small molecular weight, has been proposed as a new format that contributes to deeper tumor tissue distribution, affording stable generation of ADCs [18]. Nevertheless, the design of antibody formats needs to strike a favorable balance between reduced molecular weight and decreased plasma half-life, which can facilitate and vitiate tumor uptake, respectively. 


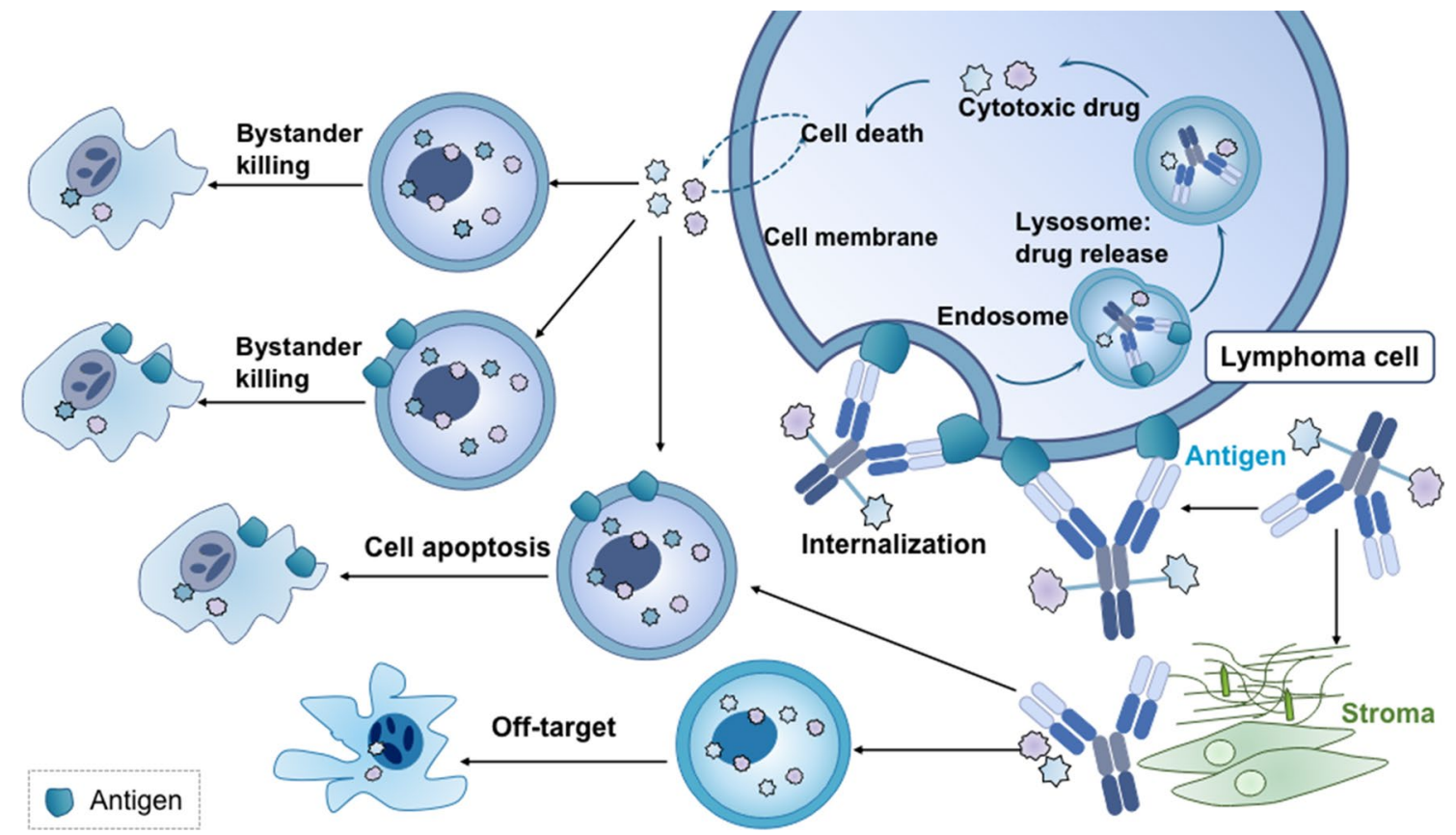

Fig. 2 ADC mechanisms of action. Once bound to the corresponding cell-surface antigen of cancer cells, the ADC is internalized, and the cytotoxic payload is released, resulting in cell apoptosis. The drug can also diffuse into adjacent cells regardless of antigen positivity, resulting in cell death, termed "bystander killing"

\section{Alternative payloads}

The cytotoxic payloads, as the final effector component, should meet core requirements, such as having strong potency in the minute range within which they are released. The payloads that have been validated in the clinic are categorized into two major groups, namely, DNA-interacting agents (e.g., duocarmycin, calicheamicin, doxorubicin, camptothecin analogs, and pyrrolobenzodiazepine [PBD] dimers) or tubulin inhibitors (e.g., maytansines and auristatins). Inotuzumab ozogamicin (InO) employs calicheamicin as an efficient payload and has been investigated in multiple lymphoid malignancies, including diffuse large B cell lymphoma (DLBCL), mantle cell lymphoma (MCL), and follicular lymphoma (FL) [19-21]. PBD dimers target DNA minor grooves and therefore cause DNA alkylation. ADCT-301 and ADCT-402, which deliver PBD dimers, are under development [22, 23].

Tubulin inactivators, the auristatins monomethyl auristatin $\mathrm{E}$ (MMAE), and monomethyl auristatin $\mathrm{F}$ (MMAF) impede microtubule polymerization, leading to cell apoptosis. MMAE is employed in Pola and BV [24, 25], and MMAF is utilized in denintuzumab mafodotin [26]. In addition, MMAE, unlike MMAF, yields bystander effect in vivo [27]. Maytansine derivatives are mainly divided into two categories: DM1 and DM4. DM1 agents are highly potent maytansinoids (emtansine and mertansine) that have broad killing effects on non-Hodgkin lymphoma (NHL) xenografts in vivo [28]. DM4 agents comprise soravtansine and ravtansine (e.g., coltuximab ravtansine), which can augment the bystander effect of adjacent cells in vivo, thereby eradicating tumors $[29,30]$.

Compared with anti-microtubule payloads, DNAdamaging agents can provide higher potency and enable ADCs to target less abundant tumor antigens [31]. A trend of assessing DNA-interacting agents as ADC payloads has been emerging $[32,33]$. Indolinobenzodiazepine dimers (termed IGNs), a novel chemical class of DNA-interfering payloads, feature enhanced bystander effect and tolerability as well as expanded therapeutic utility [34]. Seco-CBI dimers, a class of duocarmycin analogs, are presently being explored in NHL and are conjugated to anti-CD22 mAb, affording a more durable response and higher activity in indolent NHL [35].

\section{Linkers and site-specific conjugation}

Linkers provide a functional handle for efficient conjugation to antibodies. At present, cleavable and noncleavable linkers are two major classes widely applied in the clinical setting. Due to their ability to liberate diffusible payloads, cleavable linkers are implemented in a broad range of tumor types. Three main types of cleavable linkers respond to physiological stimuli, 
Table 1 Antibody-drug conjugates in clinical trials for lymphoma

\begin{tabular}{|c|c|c|c|c|c|c|}
\hline$A D C$ & Target & Linker & Payload & Indication & Result & Trial \\
\hline \multicolumn{7}{|c|}{ ADCs approved for lymphoma } \\
\hline \multirow[t]{16}{*}{ Brentuximab vedotin } & CD30 & Val-Cit & MMAE & $\mathrm{R} / \mathrm{RHL}$ & ORR 75\%, CR 34\% & phase II [48] \\
\hline & & & & $\mathrm{R} / \mathrm{RHL}$ & $\begin{array}{l}\text { ORR } 54.4 \% \text {, median PFS } \\
8.2 \text { months }\end{array}$ & phase III [49] \\
\hline & & & & $\mathrm{R} / \mathrm{RHL}$ & ORR $75 \%$, CR $42 \%$ & phase I [51] \\
\hline & & & & Post-ASCT consolidation for $\mathrm{HL}$ & $\begin{array}{l}\text { Median PFS } 42.9 \text { months, } \\
\text { 5-year PFS 59\% }\end{array}$ & phase III [52] \\
\hline & & & & Post-ASCT consolidation for $\mathrm{HL}$ & $\begin{array}{l}\text { 18-month PFS 95\%, 18-month } \\
\text { OS } 98 \%\end{array}$ & phase II [53] \\
\hline & & & & Salvage therapy for $\mathrm{R} / \mathrm{R} \mathrm{HL}$ & 2-year OS 95\%, 2-year PFS 74\% & phase II [54] \\
\hline & & & & Salvage therapy for $\mathrm{R} / \mathrm{R} \mathrm{HL}$ & ORR 84\%, CR 79\% & phase II [55] \\
\hline & & & & Salvage therapy for R/R HL & $\begin{array}{l}\text { ORR } 85 \%, \text { CR 67\%, 2-year PFS } \\
78 \%\end{array}$ & phase I/II [56] \\
\hline & & & & Untreated HL & $\begin{array}{l}\text { ORR } 86 \% \text {, CR } 73 \% \text {, 5-year PFS } \\
82 \%\end{array}$ & phase III [58] \\
\hline & & & & Untreated HL & ORR $61 \%$, CR 48\% & phase II [59] \\
\hline & & & & $\mathrm{R} / \mathrm{R} \mathrm{ALCL}$ and $\mathrm{R} / \mathrm{R} \mathrm{MF}$ & $\begin{array}{l}\text { ORR4 56.3\%, CR } 16 \% \text {, median } \\
\text { PFS } 17.2 \text { months }\end{array}$ & phase III [60] \\
\hline & & & & R/R CTCL and R/R PTCL & ORR 38\%, CR 17\% & phase II [61] \\
\hline & & & & Untreated PTCL & $\begin{array}{l}\text { ORR } 83 \% \text {, CR 68\%, 5-year PFS } \\
51 \%\end{array}$ & phase III [63] \\
\hline & & & & Untreated ALCL & 2-year EFS 79\%, 2-year OS 97\% & phase II [64] \\
\hline & & & & $\begin{array}{l}\text { R/R PMBCL and R/R mediastinal } \\
\text { GZL }\end{array}$ & $\begin{array}{l}\text { PMBCL: ORR 73\%, CR 37\% } \\
\text { Mediastinal GZL: ORR 70\%, CR } \\
50 \%\end{array}$ & phase I/II [67] \\
\hline & & & & $\begin{array}{l}\text { Untreated PMBCL, DLBCL, and } \\
\text { GZL }\end{array}$ & $\begin{array}{l}\text { ORR 100\%, CR 86\%, 2-year PFS } \\
85 \% \text {, }\end{array}$ & phase I/II [68] \\
\hline \multirow[t]{5}{*}{ Polatuzumb vedotin } & $\mathrm{CD} 79 \mathrm{~b}$ & Val-Cit & MMAE & $\mathrm{R} / \mathrm{R} \mathrm{DLBCL}$ and R/R FL & $\begin{array}{l}\text { FL: ORR 70\%, CR 45\%; } \\
\text { DLBCL: ORR 54\%, CR } 21 \%\end{array}$ & phase II [71] \\
\hline & & & & $\mathrm{R} / \mathrm{R} \mathrm{DLBCL}$ & $\begin{array}{l}\text { ORR } 45 \% \text {, CR } 40 \% \text {, median OS } \\
12.4 \text { months, }\end{array}$ & phase II [25] \\
\hline & & & & $\mathrm{R} / \mathrm{R} \mathrm{DLBCL}$ & $\begin{array}{l}\text { ORR } 65 \% \text {, CR } 31 \% \text {, median DOR } \\
5.8 \text { months }\end{array}$ & phase I/II [72] \\
\hline & & & & $\mathrm{R} / \mathrm{RFL}$ & ORR 76\%, CR 65\% & phase I/II [73] \\
\hline & & & & Untreated DLBCL & ORR 89\%, CR 77\% & phase I/II [74] \\
\hline \multirow[t]{2}{*}{ Loncastuximab tesirine } & CD19 & Val-Ala & PBD dimer & $\mathrm{R} / \mathrm{R} N H \mathrm{~L}$ & $\begin{array}{l}\text { ORR } 46 \%, \text { CR 27\%, median DOR } \\
5.4 \text { months }\end{array}$ & phase I [76] \\
\hline & & & & $\mathrm{R} / \mathrm{R} \mathrm{DLBCL}$ & $\begin{array}{l}\text { ORR 48\%, CR 24\%, median DOR } \\
10.3 \text { months }\end{array}$ & phase II [78] \\
\hline \multicolumn{7}{|c|}{ ADCs explored in clinical settings } \\
\hline \multirow[t]{2}{*}{ Coltuximab ravtansine } & CD19 & SPDB & DM4 & R/R DLBCL & ORR 44\%, CR 15\% & phase II [79] \\
\hline & & & & $\mathrm{R} / \mathrm{R} \mathrm{DLBCL}$ & ORR 31\% & phase II [81] \\
\hline SGN-CD19A & CD19 & MC & MMAF & R/R B-NHL & $\begin{array}{l}\text { ORR 33\%, CR22\%, median DOR } \\
40 \text { weeks }\end{array}$ & phase I [82] \\
\hline MT-3724 & CD20 & / & SLTA & $\mathrm{R} / \mathrm{R} \mathrm{DLBCL}$ & ORR 30\%, CR 10\% & phase I [100] \\
\hline \multirow[t]{5}{*}{$\begin{array}{l}\text { Inotuzumab ozo- } \\
\text { gamicin }\end{array}$} & CD22 & Acid-labile & $\begin{array}{l}\text { Calicheam- } \\
\text { icin }\end{array}$ & $\mathrm{R} / \mathrm{R} \mathrm{NHL}$ & $\begin{array}{l}\text { FL: ORR 87\%, 2-year PFS 68\% } \\
\text { DLBCL: ORR 74\%, 2-year PFS } \\
\text { 42\% }\end{array}$ & phase III [88] \\
\hline & & & & R/R NHL & ORR $41 \%, 18$-month OS $35 \%$ & phase III [89] \\
\hline & & & & R/R NHL & ORR 53\%, CR 20\% & phase I [90] \\
\hline & & & & $\mathrm{R} / \mathrm{R} \mathrm{B}-\mathrm{NHL}$ & ORR 84\%, CR 24\% & phase I [91] \\
\hline & & & & $\mathrm{R} / \mathrm{R}$ indolent $\mathrm{B}-\mathrm{NHL}$ & $\begin{array}{l}\text { ORR } 67 \% \text {, CR 31\%, median PFS } \\
12.7 \text { months }\end{array}$ & phase II [92] \\
\hline
\end{tabular}


Table 1 (continued)

\begin{tabular}{|c|c|c|c|c|c|c|}
\hline ADC & Target & Linker & Payload & Indication & Result & Trial \\
\hline \multirow[t]{2}{*}{ Pinatuzumab vedotin } & CD22 & Protease-cleavable & MMAE & $\begin{array}{l}\text { R/R DLBCL and R/R indolent } \\
\text { NHL }\end{array}$ & $\begin{array}{l}\text { DLBCL: ORR 36\%, } \\
\text { Indolent NHL: ORR 50\% }\end{array}$ & phase I [96] \\
\hline & & & & $\mathrm{R} / \mathrm{R} \mathrm{DLBCL}$ and $\mathrm{R} / \mathrm{R} \mathrm{FL}$ & $\begin{array}{l}\text { DLBCL: ORR 60\%, CR 26\%; } \\
\text { FL: ORR } 62 \%, \text { CR } 5 \%\end{array}$ & phase II [71] \\
\hline \multirow[t]{2}{*}{ TRPH-222 } & CD22 & Non-cleavable & Maytansinoid & $\mathrm{R} / \mathrm{R} N H \mathrm{~L}$ & ORR 27.2\%, CR 22.7\% & phase I [97] \\
\hline & & & & $\mathrm{R} / \mathrm{RHL}$ & $\begin{array}{l}\text { ORR } 69 \% \text {, CR } 44 \% \text {, median } \\
\text { DOR } 7.7 \text { months, median PFS } \\
6.7 \text { months }\end{array}$ & phase I [109] \\
\hline IMGN529 & CD37 & SMCC & DM1 & R/R B-NHL & ORR 13\% & phase I [113] \\
\hline AGS67E & CD37 & Val-Cit & MMAE & $\mathrm{R} / \mathrm{R} \mathrm{NHL}$ & ORR 22\%, CR 14\% & phase I [116] \\
\hline STRO-001 & CD74 & Non-cleavable & Maytansinoid & Advanced B cell malignancies & ORR 25\%, CR 6.3\% & phase I [125] \\
\hline Iladatuzumab vedotin & CD79b & Protease-cleavable & MMAE & $\mathrm{R} / \mathrm{R}$ B-NHL & $\begin{array}{l}\text { ORR 85\%; DLBCL: ORR 60\%, } \\
\text { CR 43\% }\end{array}$ & phase I [128] \\
\hline VLS-101 & ROR1 & UC-961 & MMAE & R/R NHL & $\begin{array}{l}\text { MCL: ORR 47\%, CR 20\%; } \\
\text { DLBCL: ORR 80\%, CR 40\% }\end{array}$ & phase I [131] \\
\hline
\end{tabular}

ADC, antibody-drug conjugate; $A S C T$, autologous stem cell transplantation; $A L C L$, anaplastic large cell lymphoma; $C T C L$, cutaneous T cell lymphoma; $H L$, Hodgkin lymphoma; NHL, non-Hodgkin lymphoma; R/R, relapsed or refractory; $C R$, complete response; $D L B C L$, diffuse large $B$ cell lymphoma; $D O R$, duration of response; $\mathrm{FL}$, follicular lymphoma; MCL, mantle cell lymphoma; GZL, gray zone lymphoma; CLL, chronic lymphocytic leukemia; PTCL, peripheral T cell lymphoma; MF, mycosis fungoides; ORR, overall response rate; OS, overall survival; PFS, progression-free survival; EFS, event-free survival; ORR4, ORR lasting at least 4 months

such as low pH: acid-labile hydrazone linkers, disulfide linkers, and protease-cleavable linkers. $N$-succinimidyl-4-(2-pyridyldithio)-pentanoate (SPP) and $N$-succinimidyl-4-(2-pyridylthio)-butanoate (SPDB) represent two classes of disulfide linkers that are unstable at high glutathione concentrations (e.g., used in the maytansinoid-based ADC naratuximab emtansine). Protease-cleavable linkers, the most stable type, comprise dipeptide sequences such as valine-citrulline (Val-Cit) and valine-alanine (Val-Ala) that are generally cleaved by cathepsin B intracellularly (e.g., that used in Pola). Nonetheless, sufficient extracellular proteolytic cleavage of the Val-Cit linker is also observed, indicating that endocytosis of $\mathrm{ADC}$ is not required under certain conditions and that developing non-internalizing antibodies may be a potential option for increasing antitumor activity [36].

Concerning the pursuit of increased plasma stability, non-cleavable linkers appear to be a better option for ADCs. Non-cleavable linkers mainly depend on sufficient processing of mAbs within the lysosome after ADC internalization to release the toxin due to the lack of cell permeability. These linkers are accompanied by limited bystander effect and have lower membrane permeability.

The attachment between mAb and linker is a crucial parameter of ADCs as it determines the drug-to-antibody ratio (DAR) and consequently the stability, efficacy, and homogeneity of the ADCs. Site-specific methods are proposed to optimize the DAR and maintain favorable pharmacokinetics while maximizing payloads in the development of ADCs. Several site-specific conjugation approaches that utilize integrated non-natural amino acids, engineered cysteine residues [37] or enzymatic modifications, including transglutaminases [38], sortase A [39], glycosyltransferase [40] and formylglycine-generating enzyme [41], have been reported. The chemoenzymatic approach can harvest a high yield of ADCs with suitable DARs and attractive conjugation efficiency by achieving site-specific conjugation and generating precisely controlled modification sites [42].

The site-specific method has enabled the generation of multivalent conjugated drugs. For example, a heterotrifunctional linker was designed to prepare a dual-cytotoxic (MMAE and DM1) drug conjugate in a site-specific manner, highlighting the potential of ADCs with distinct mechanisms of action for targeting neoplasms and attaining obvious synergy compared with single agents [43]. Additionally, dual-drug combinations also offer possibilities for circumventing ADC-related drug resistance in practice [44]. Therefore, selection and design strategies are complementary and particularly powerful when used in combination.

\section{ADCs approved for lymphoma}

\section{Brentuximab vedotin}

CD30, a transmembrane glycoprotein belonging to the tumor necrosis factor (TNF) receptor superfamily, is expressed on a small subset of activated $\mathrm{B}$ and $\mathrm{T}$ lymphocytes and restricted to normal tissues. CD30 is of high interest as a therapeutic target for antibody-based treatments owing to its excessive and selective expression on 
cancer cells [45]. The prognostic and therapeutic impacts of CD30 expression have been investigated in Hodgkin lymphoma (HL), anaplastic large cell lymphoma (ALCL), cutaneous T cell lymphoma (CTCL), and primary mediastinal B cell lymphoma (PMBCL) $[7,46]$.

BV comprises a CD30 targeting chimeric IgG1 mAb, an MMAE payload moiety, and a Val-Cit linker. A series of studies have explored the clinical benefits of BV in diverse settings, such as second-line therapy for relapsed or refractory $(\mathrm{R} / \mathrm{R})$ disease, consolidation therapy, salvage therapy, and frontline therapy in HL (Table 1). The encouraging results led to the approval of $\mathrm{BV}$ by the U.S. FDA for patients with relapsed classical Hodgkin lymphoma (cHL) and relapsed ALCL [47]. In a pivotal phase II study of BV monotherapy, the overall response rate (ORR) was $75 \%$, with $34 \%$ complete response (CR) in patients with $\mathrm{R} / \mathrm{R}$ HL who failed autologous stem cell transplantation (ASCT) [48]. For patients achieving a $C R$, the median duration of response (DOR) was 20.5 months, with 5-year progression-free survival (PFS) and overall survival (OS) rates of $52 \%$ and $64 \%$, respectively. The most common side effects related to the drug were peripheral neuropathy (PN), nausea, fatigue, neutropenia, and diarrhea. In the phase III KEYNOTE-204 study (NCT02684292) involving patients with R/R cHL who had received more than two prior therapies and were treated with BV or pembrolizumab (a PD-1 inhibitor) monotherapy, the ORR was $54 \%$ for the BV arm and $65 \%$ for the pembrolizumab arm [49]. The reported median PFS was 8.2 months for BV and 12.6 months for pembrolizumab. For patients experiencing severe adverse effects (AEs), the proportion was comparable in the BV and pembrolizumab arms (24\% vs. $23 \%)$. This trial suggested the potential benefit of BV and pembrolizumab combination therapy in patients who are heavily pretreated. Nonetheless, some patients will ultimately develop BV resistance and may partially attribute to the upregulation of NF-kappaB [50] or multidrug resistance pump (MDR1) [51]. The combination therapy of BV and cyclosporine A (an MDR1 inhibitor) was recently examined in a phase I trial (NCT03013933) to combat BV resistance in cHL, which reported an ORR of $75 \%$, a CR rate of $42 \%$, and a modest toxicity profile [51].

The phase III AETHERA trial (NCT01100502) measured the efficacy and safety profiles of BV in patients with cHL in the post-transplant consolidation setting [52]. The 5 -year PFS rates were 59\% in patients with BV and $43 \%$ in patients with placebo. The most common AEs associated with the therapeutic agent included neurotoxicity (67\%), infection (60\%), and neutropenia (35\%). The majority of PN and neutropenia cases were reversible and managed with dose delay or reduction. Recently, a phase II study evaluated the results of 59 participants with
$\mathrm{R} / \mathrm{R}$ aggressive $\mathrm{HL}$ receiving $\mathrm{BV}$ and nivolumab (Nivo), a PD-1 inhibitor, as post-ASCT consolidation therapy [53]. The estimated 18-month OS and PFS rates were $98 \%$ and $95 \%$, respectively. Treatment was well tolerated, with common AEs of PN (51\%) and neutropenia (42\%). The encouraging results suggested that BV plus Nivo may provide prolonged remission in patients at an advanced stage.

The incorporation of BV in salvage therapy for patients with $R / R$ diseases has been evaluated by a few studies. One phase II study (NCT02280993) including $55 \mathrm{R} / \mathrm{R}$ cHL patients treated with BV plus dexamethasone, cisplatin, and cytarabine (DHAP) with a PFS rate of $74 \%$ and OS rate of $95 \%$ at the 2-year follow-up was recently reported [54]. For patients who proceeded to ASCT, 42 patients achieved a metabolic CR and 5 achieved a metabolic partial response (PR). A BV and bendamustine regimen also provided a robust efficacy benefit in HL patients in a single-arm multicenter phase II study [55]. The ORR was $84 \%$, with 30 patients (79\%) achieving a $\mathrm{CR}$ and 2 patients (5\%) achieving a PR. In addition, 33 patients underwent ASCT. The estimated 3-year OS and PFS rates were also promising, at $88 \%$ and $67 \%$, respectively. Skin reactions were rather frequent (65\%) and should be monitored during treatment. Recently, BV plus Nivo therapy, the first chemo-free combination, was reported to have an ORR of $85 \%$ and a CR rate of $67 \%$ for all treated patients with cHL in a phase I/II trial (NCT02572167) [56]. The estimated 2-year PFS rate in all enrolled patients was $78 \%$. For patients who proceeded to ASCT after receiving BV + Nivo, the proportion was $91 \%$, suggesting that further exploration of this combination treatment as a bridge to ASCT in a larger cohort is warranted.

The approval for frontline use in combination with chemotherapy was based on the impressive activity and manageable safety profiles observed in the phase III ECHELON-1 trial in advanced-stage cHL [57]. Updated data from the ECHELON-1 cohort (NCT01712490) demonstrated an overall risk-benefit ratio favoring the BV plus doxorubicin, vinblastine, and dacarbazine (A+AVD) arm over the doxorubicin, bleomycin, vinblastine, and dacarbazine (ABVD) arm in patients with previously untreated cHL irrespective of prognostic risk score [58]. At a 5-year follow-up, a durable efficacy benefit was found in participants receiving A+AVD compared with ABVD, with an improved PFS rate $(82 \%$ vs. $75 \%)$, albeit with a comparable ORR (86\% vs. $83 \%)$ and $\mathrm{CR}$ rate $(73 \%$ vs. $70 \%)$. A higher incidence of $\mathrm{PN}$ was seen in the A + AVD (67\% vs. $43 \%)$ arm with an increased rate of febrile neutropenia (19\% vs. $8 \%$ ) and a decreased rate of pulmonary-related toxicity ( $2 \%$ vs $7 \%$ ). ABVD therapy was considered unsuitable for further development based 
on a relatively high incidence of pulmonary-related toxicity. In a single-arm, phase II trial (NCT02758717), elderly patients who were considered unsuitable for standard chemotherapies received BV + Nivo with an ORR of $61 \%$ and a CR rate of 48\% [59]. Neurotoxicity was noted in 14 $(30 \%)$ of 46 patients and may have accounted for dose adjustments. Currently, a phase III trial (NCT03907488) of the A+AVD arm versus the Nivo + AVD arm is undergoing in patients with newly diagnosed advancedstage HL.

BV has been evaluated in various types of R/R NHL, including mycosis fungoides (MF) and primary cutaneous ALCL. Efficacy analysis was conducted in a pooled population of 128 patients with CD30-positive MF or primary cutaneous ALCL who failed prior systemic therapies and were enrolled in the multicenter randomized phase III trial (ALCANZA) [60]. ORR lasting at least 4 months (ORR4) intensely favored the BV arm compared to the control (methotrexate or bexarotene) arm $(56.3 \%$ vs. 12.5\%). Notably, this favorable clinical efficacy of the BV group was observed for other endpoints, such as CR rate (16\% vs. $2 \%)$ and median PFS (17.2 vs. 3.5 months), and manifested as a reduction in tumor burden. Grade 3 to 4 adverse events were reported less frequently in the BV group than in the control group ( $41 \%$ vs. $47 \%$ ), while PN was seen frequently in the BV group (67\% vs. $6 \%)$, most of which were grade 1 to 2 . Studies combining BV with other immunomodulatory agents or chemotherapies have revealed improvements in outcomes, compared with BV monotherapy. The initial outcomes of a phase II study of BV and lenalidomide (Len) in heavily pretreated subjects with R/R CTCL and R/R PTCL reported a CR rate of $17 \%$, a PR rate of $25 \%$, and an ORR of $38 \%$ [61]. Recruitment of both CTCL and PTCL patients for this trial is ongoing (NCT03409432). BV has also been shown to be effective in patients with newly diagnosed PTCL. The ECHELON-2 trial (NCT01777152) observed a consistent response and an OS benefit in aggressive PTCL (predominantly ALCL) with the BV, cyclophosphamide, doxorubicin, and prednisone $(\mathrm{A}+\mathrm{CHP})$ regimen compared with a proven standard therapy (CHOP) [62]. The A + CHP group had a superior 5 -year PFS rate $(51 \%$ vs. $43 \%)$, an improved CR rate (68\% vs. $56 \%$ ) and ORR ( $83 \%$ vs. $72 \%$ ), and slightly increased toxicity [63]. The addition of BV in frontline therapy for ALCL has also been evaluated in several studies in the hope of improving cure rates. A recently reported phase II trial enrolled 68 pediatric patients with newly diagnosed ALCL and treated them with BV in combination with standard chemotherapy [64]. The 2-year event-free survival (EFS) rate was $79 \%$, and the 2 -year OS rate was $97 \%$, with no cases of severe neuropathy occurred, suggesting that the addition of BV to standard chemotherapies may be tolerable and used to prevent relapses in children.

Additionally, the BV plus Len regimen has also been explored in patients with $\mathrm{R} / \mathrm{R}$ DLBCL who relapsed after hematopoietic stem cell transplantation (HSCT) and were in need of novel therapies. Data from a phase I trial showed an ORR of $57 \%$ in 37 subjects and an ORR of $73 \%$ in the CD30-positive subgroup $(n=15)$ [65]. The encouraging results of BV plus Len regimen led to assessments of efficacy in combination with Len and rituximab versus placebo in combination with Len and rituximab in a phase III study (NCT04404283) for patients with $\mathrm{R} / \mathrm{R}$ DLBCL. Moreover, a combination with immune checkpoint inhibitors could be a feasible option for $R / R$ B-NHL [66]. The BV plus Nivo regimen has shown activity in patients with $\mathrm{R} / \mathrm{R}$ PMBCL who have received at least two prior therapies, and exhibited advantages over the use of PD-1 inhibitor or BV alone [7]. Efficacy analysis of 30 patients in the phase I/II study (NCT02581631) reported an ORR of $73 \%$, with $37 \%$ of patients achieving a CR. Notable treatment-emergent adverse events (TEAEs) included PN (10\%) and thrombocytopenia (10\%). Three patients discontinued treatment owing to severe $\mathrm{PN}$. The updated data of the trial showed an ORR of $70 \%$ $(50 \% \mathrm{CR})$ and a tolerable safety profile in 10 patients with $R / R$ mediastinal gray zone lymphoma (GZL) receiving BV + Nivo [67]. The time to CR was 1.2 months and 5 patients who achieved a CR were bridged to HSCT. Based on the high CR rate, this regimen may provide an alternate option for bridging to hematopoietic cell transplantation. Furthermore, the BV combined with rituximab, cyclophosphamide, doxorubicin, and prednisone (R-CHP) regimen was also assessed as frontline therapy in a phase I/II multicenter trial (NCT01994850) using 6 cycles of treatment to assess toxicity and efficacy for 29 patients with CD30-positive B cell lymphomas, including 22 PMBCL, 5 DLBCL, and 2 GZL [68]. After systemic treatment was administered, the ORR was $100 \%$, with $86 \%$ of patients achieving a CR by the time therapy was completed. The 2-year PFS and OS rates were $85 \%$ and $100 \%$, respectively. Subtype analysis revealed that the 2 -year PFS rate in patients with PMBCL was $86 \%$. The treatment may provide durable responses for patients with CD30-positive B cell lymphomas and warrants further exploration. Thus, BV-based therapies may be efficacious and safe treatment options for patients at a high risk of relapse.

\section{Polatuzumab vedotin}

$\mathrm{CD} 79 \mathrm{~b}$ is a component of the $\mathrm{B}$-cell receptor (BCR) complex required for proper cellular localization, trafficking, and signal transduction [69]. CD79b is restricted to B cells and highly prevalent in B cell leukemia and 
lymphoma with minimal expression in normal tissue, appearing ideally suited to serve as the targeting moiety [70].

The Pola structure contains an anti-CD79b mAb sitespecifically coupled with MMAE through a Val-Cit linker similar to the structure of the anti-CD22 ADC pinatuzumab vedotin (Pina). The multicenter, phase II ROMULUS study (NCT01691898) illustrated that rituximab plus Pola (R-pola) showed significant benefit over rituximab plus Pina (R-pina) in patients with R/R DLBCL and $\mathrm{R} / \mathrm{R} \mathrm{FL}$, and both arms compared favorably with other rituximab-based immunochemotherapy arms [71]. Regardless of CD79b or CD22 expression level, R-pola was related to a more favorable outcome in the FL subgroup, including an ORR of $70 \%(45 \% \mathrm{CR})$ and a median PFS of 15.3 months. In DLBCL patients, the R-pola arm showed a comparable ORR ( $54 \%$ vs. $60 \%$ ) and CR rate ( $21 \%$ vs. $26 \%$ ) with the control arm. In addition, R-pola was associated with fewer grade 3 or higher side effects in both the DLBCL and FL cohorts.

Currently, there is no standard treatment strategy for some patients with R/R DLBCL who are transplantineligible and for those who relapse after HSCT. In a multicenter phase II trial (NCT02257567), patients were randomly assigned to the Pola plus bendamustine and rituximab (pola-BR) arm or bendamustine plus rituximab (BR) arm. The results showed that compared with the BR group, the ORR ( $45 \%$ vs. $18 \%$ ), CR rate ( $40 \%$ vs. $17.5 \%)$, median OS (12.4 vs. 4.7 months), and PFS (9.5 vs. 3.7 months) in the pola-BR arm were significantly improved, and the AEs were acceptable [25]. Another phase Ib/II trial (NCT02611323) investigated the efficacy and tolerability of a novel triplet combination (Pola, venetoclax, and rituximab) in 57 participants with $R / R$ DLBCL [72]. The reported ORR and CR rate were $65 \%$ and $31 \%$, respectively, with a median DOR of 5.8 months. Notable AEs causing dose reduction or interruption of any drug occurred in $18 \%$ and $61 \%$ of patients, respectively. Further evaluation of this combination is warranted due to the limited number of patients recruited. Based on the aforementioned data, Pola is also under exploration in patients with $\mathrm{R} / \mathrm{R} \mathrm{MCL}$ in an ongoing phase II trial (NCT04659044) that is recruiting patients receiving the same combination therapy of Pola, venetoclax, and rituximab.

The benefit of adding Pola in combination with other immunotherapies has been explored in a few studies. A phase Ib/II study (NCT02600897) sought to determine the efficacy and safety profiles of a triplet combination of Pola, obinutuzumab (G), and lenalidomide (Pola-GLen) in patients with $\mathrm{R} / \mathrm{R}$ FL [73]. The ORR was $76 \%$, with a CR rate of $65 \%$ in the primary efficacy population $(n=46)$. Of those patients who were refractory to their last treatment, $71 \%$ achieved a CR. Grade 3 or worse adverse events included neutropenia (50\%), thrombocytopenia (23\%), infections (16\%), and anemia (14\%). TEAEs causing a dose reduction or cycle cessation arose in $19(34 \%)$ and 41 (73\%) patients, respectively, and the majority were attributed to intolerability of Len. A more extended period of follow-up, through and beyond maintenance treatment, is ongoing. Despite the desirable antitumor activity of triplet therapy, optimization of doses or prophylactic use of granulocyte colony stimulating factor (G-CSF) is needed to reduce the incidence of AEs.

An open-label, non-randomized phase Ib/II study (NCT01992653) focused on incorporating Pola into the $\mathrm{R}-\mathrm{CHP}$ or G-CHP regimen as one of the frontline treatments in adult patients with DLBCL, the desirable outcomes of which contributed to FDA approval [74]. Among patients receiving Pola in combination with chemotherapy, an encouraging response with an ORR of $89 \%$ (77\% CR) was achieved. Instances of severe myelosuppression included neutropenia (30\%), febrile neutropenia (18\%), and thrombocytopenia (9\%). In light of the encouraging data mentioned above, a phase III, doubleblind POLARIX trial (NCT03274492) is undergoing to investigate whether Pola combination therapy (Pola-RCHP) can be clinically advantageous in certain DLBCL subtypes. In addition, Pola-R-CHP has shown a more favorable efficacy than the proven therapy (R-CHOP) as the frontline regimen for patients with previously untreated DLBCL. Other uncompleted phase I/II studies have investigated various types of lymphomas, such as newly diagnosed double- or triple-hit lymphoma (NCT04479267) and untreated aggressive B cell lymphoma (NCT04231877).

\section{Loncastuximab tesirine}

CD19 is a $95 \mathrm{kDa}$ glycoprotein that is critically involved in the processes of $\mathrm{B}$ cell proliferation, differentiation, activation, and antibody production, and it can also promote BCR signal transduction. As a biomarker, CD19 is prevalently expressed in $B$ cell malignancies and is thought to be the most reliable surface biomarker for $B$ cells [75].

Loncastuximab tesirine (ADCT-402), which was recently approved for use in patients with $R / R$ large $B$ cell lymphoma, comprises a humanized $\mathrm{mAb}$ specifically directed to CD19, a PBD dimer, and a cleavable disulfide-bond linker. The results of 183 patients with $\mathrm{R} / \mathrm{R}$ NHL who received loncastuximab tesirine in the phase I dose-expansion study (NCT02669017) reported an ORR of $46 \%$ and a CR rate of $27 \%$ with a median DOR of 5.4 months [76]. Among patients in the DLBCL, MCL, and FL subgroups, the ORRs were $42 \%, 47 \%$, and $79 \%$, respectively. Notably, the ORR was $56 \%$ in the subgroup 
of elderly patients ( $\geq 75$ years old) with DLBCL, indicating encouraging efficacy. The patients tolerated the therapy well because the treatment-related toxicities were largely hematologic and generally manageable with dose delays, followed by fatigue, nausea, edema, and hepatotoxicity, while dose-limiting toxicities (DLTs) were reported in only 4 patients. The rapid onset of response also supported the further development of loncastuximab tesirine when compared with the new combination therapy of tafasitamab plus Len in patients with $R / R$ DLBCL (1.5 vs. 2.0 months) [77]. Given the small number of patients in the FL subgroup $(n=14)$, larger randomized studies are needed for validation. The updated analysis of data from a phase II trial (NCT03589469) reported an ORR of $48 \%$, a CR rate of $24 \%$ and a median DOR of 10.3 months in 145 evaluable patients with R/R DLBCL with a $26 \%$ frequency of severe neutropenia and a $17 \%$ frequency of grade 3 to 4 glutamyltransferase (GGT) increase [78]. The data also revealed an ORR of $46 \%$ among patients who failed prior CD19-directed chimeric antigen receptor $\mathrm{T}$ cell (CAR-T) therapy, indicating that these immunotargeted agents may be used consequentially in high-risk patients. A survival advantage was also noted in patients with double- or triple-hit DLBCL, with an ORR of 33\% (notably all CRs) and a median DOR of 13.4 months. Other phase I trials have explored loncastuximab tesirine as part of immunochemotherapy, such as with rituximab (NCT04384484) or ibrutinib.

\section{ADCs explored in various clinical and preclinical settings \\ Anti-CD19 ADCs \\ Coltuximab ravtansine}

Coltuximab ravtansine (SAR3419) comprises DM4, a potent tubulin inhibitor, coupled to a CD19-targeting $\mathrm{mAb}$ through an SPDB linker [79]. In a pivotal phase II study, SAR3419 was associated with an ORR of $44 \%$ and a CR rate of $15 \%$ in 41 eligible patients with $R / R$ DLBCL who had previously received rituximab-containing immunochemotherapy [80]. Patients who received SAR3419 based on a schedule of 4 weekly doses followed by 4 biweekly administrations had moderate grade 1-2 myelosuppression, ocular toxicity, and neurotoxicity reported at grade 1 to 2 . The estimated median OS for all treated patients was 9.2 months, with a median PFS of 4.4 months. The ORR, the primary endpoint, was unfavorable (31\%) in 45 patients with R/R DLBCL in a multicenter phase II study of SAR3419 and rituximab [81]. The results were possibly due to the high proportion of patients with primary refractory disease in the trial. The treatment-related toxicities were mainly gastrointestinal symptoms (52\%) and asthenia (25\%). Although the drug is well tolerated, its development remains challenging because of its undesirable efficacy.

\section{Denintuzumab mafodotin}

Denintuzumab mafodotin (SGN-CD19A) is an ADC aimed at CD19 formed by conjugation of a potent microtubule-acting agent, MMAF, to a humanized anti-CD19 IgG1 mAb through a non-cleavable linker. In a phase I trial, $33 \%$ of patients with R/R B-NHL who received at least one prior salvage therapy responded to denintuzumab mafodotin monotherapy (22\% CR), achieving a median DOR of 40 weeks and low incidence rates of hematological disorders and neuropathy [82]. In the subgroup of relapsed patients, promising outcomes were observed in terms of the ORR $(60 \%)$ and CR rate $(40 \%)$ as well as a long-lasting response (median DOR, 47 weeks). Of note, reversible ocular disorders such as superficial microcystic keratopathy occurred in $84 \%$ of patients. The results of subsequent phase II trials, however, did not confirm therapeutic efficacy. One study (NCT02855359) was terminated because severe hematological AEs occurred in all recruited patients, with two fatal cases reported, which were likely due to severe myelosuppression and infections. Another trial (NCT02592876) was also discontinued based on the similar toxicity (e.g., febrile neutropenia) observed in the denintuzumab mafodotin plus rituximab, ifosfamide, carboplatin, etoposide, and mesna (RICE) arm for participants with DLBCL.

\section{Anti-CD22 ADCs}

$\mathrm{CD} 22$, whose expression is restricted to mature B lineage cells, imposes modulatory effects on diverse signaling pathways that allow appropriate B cell homeostasis, survival, and activation [83]. CD22 is a recycling endocytic receptor that shuttles toxins between the cell surface and endosomes, leading to rapid internalization [84]. The anti-CD22-based treatment already provides a path forward to overcome the poor prognosis of $R / R$ B lineage lymphomas.

\section{Inotuzumab ozogamicin}

$\mathrm{InO}$ is composed of a humanized anti-CD22 IgG4 mAb, a hydrazone linker, and a calicheamicin derivative as its payload. It was initially applied in acute lymphoblastic leukemia (ALL) patients in various clinical settings [85-87]. The possibility of InO application in $\mathrm{R} / \mathrm{R}$ NHL is supported by data from several clinical studies [88-93], which used it in various combinations, such as with rituximab, gemcitabine, dexamethasone, and cisplatin (R-GDP) or rituximab, cyclophosphamide, vincristine, and prednisone (R-CVP) therapy. Rituximab plus InO (R-InO) treatment was associated with ORRs of $87 \%, 74 \%$, and $20 \%$ for relapsed FL, relapsed DLBCL, and 
refractory aggressive NHL, respectively, in a phase III study (NCT00299494) [88]. The 2-year PFS rate was 68\% for relapsed FL and $42 \%$ for relapsed DLBCL. Regarding another phase III trial for patients with $R / R$ aggressive $\mathrm{NHL}$, the result was somewhat disappointing because no superior therapeutic efficacy was observed in the R-InO arm compared with rituximab plus chemotherapy with bendamustine or gemcitabine arm (ORR, $41 \%$ vs. 43\%; OS, 35\% vs. 37\%) [89].

Based on the undesirable outcomes of R-InO treatment, several novel combination therapies for R/R NHL have emerged recently. A phase I study (NCT01055496) of the InO plus R-GDP regimen demonstrated manageable toxicity and relatively lower required doses in patients with R/R NHL [90]. The ORR was reported to be $53 \%$, with $20 \%$ CR and 33\% PR. Subset analysis revealed that the ORRs were $71 \%, 62 \%$, and $33 \%$ in patients with FL, DLBCL, and MCL, respectively. The major high-grade $(\geq 3)$ events were thrombocytopenia (75\%) and neutropenia (62\%). In addition, one phase I trial (NCT01055496) treated patients with R/R B-NHL with InO therapy at $0.8 \mathrm{mg} / \mathrm{m}^{2}$ plus standard-dose R-CVP [91]. The ORR was $84 \%$, and the CR rate was $24 \%$. The main toxicity (grade 3 ) associated with InO in the maximum-tolerated dose (MTD) cohort was hematological, including neutropenia (74\%), thrombocytopenia (50\%), leukopenia (47\%), and lymphopenia (42\%). Overall, the toxicity profile of this combination was consistent with those previously reported for InO alone [94] or in combination with rituximab [95]. The R-InO and R-GEMOX combinations are being compared in a phase Ib/II study (NCT01562990) in patients with DLBCL at first or second relapse. The efficacy and safety of InO were also evaluated in a phase II trial (NCT00868608) for patients with indolent B-NHL refractory to rituximab-based therapies [92]. The reported ORR (67\%) and CR rate (31\%) for all enrolled patients in this setting were promising, with a median PFS of 12.7 months. Treatment duration was restricted by hematological toxicities, particularly thrombocytopenia (74\%) and neutropenia (56\%). InO in combination with conventional chemotherapy is also tested in different settings. A phase II study (NCT03856216) aims to assess AEs and efficacy of InO plus chemotherapy in participants with lymphoma or leukemia in the pre- and post-transplantation settings.

\section{Pinatuzumab vedotin}

Pina is an ADC with a humanized anti-CD22 IgG antibody that can be linked to MMAE via an optimized protease-cleavable linker. A phase I study evaluated the feasibility of the therapeutics of R-pina and obtained its recommended phase II dose (RP2D) in R/R DLBCL and R/R indolent NHL [96]. Overall, neutropenia and PN were the most frequent causes of drug withdrawal and were the primary observed DLTs. As a result, $2.4 \mathrm{mg} / \mathrm{kg}$ every 3 weeks was designated the RP2D for both Pina alone and Pina with rituximab. With this RP2D, the ORR was $36 \%$ in R/R DLBCL and $50 \%$ in R/R indolent NHL. Furthermore, the subgroup analysis of DLBCL displayed encouraging outcomes as the ORR and CR rate of R-pina appeared superior to those of the single-agent Pina (ORR, $57 \%$ vs. $36 \%$; CR rate, $24 \%$ vs. $16 \%$, respectively). According to the results of the phase II ROMULUS study (NCT01691898), the ORR and CR rate in the 21 patients with FL receiving R-pina were $62 \%$ and $5 \%$, respectively, and the 42 patients in the DLBCL subgroup had an ORR of $60 \%$ and a CR rate of $26 \%$ [71]. Severe AEs occurred in $79 \%$ of the 42 patients with FL and $62 \%$ of the 21 patients with DLBCL. Pina was not chosen for further testing, partly because it was relatively less effective with higher grade AEs.

\section{TRPH-222}

TRPH-222 (CAT-02-106), a site-specifically conjugated ADC, targets CD22 with a maytansine payload coupled through a novel non-cleavable linker utilizing SMARTag ${ }^{\circledR}$ HIPS bioconjugation technology [97]. The preliminary result of an ongoing phase I clinical trial (NCT03682796) suggested that $5(22.7 \%)$ of 22 heavily pretreated patients were confirmed to have a CR at doses of $0.6-5.6 \mathrm{mg} / \mathrm{kg}$ with an overall favorable safety profile. Notably, no severe peripheral neuropathies, which are generally observed with ADCs containing microtubule-interacting payloads, have been observed in the patients to date. Another preclinical study revealed that TRPH-222 may be an efficacious approach for MDR1-resistant cells with no apparent side effects in NHL xenograft animal models when they were repeatedly dosed [98]. Among all tested animals, TRPH-222 induced a CR in 75\% (6 of 8) and a durable response at the end of the study in $38 \%$ of these animals. Collectively, patients may benefit from this drug, including those who become refractory to standard chemotherapies or resistant to prior immunotherapies, because of the upregulation of MDR proteins.

\section{Anti-CD20 ADCs}

Several second-generation mAbs targeting CD20, a broadly explored target in the DLBCL population, have been clinically tested, but no significant benefits have been shown for $\mathrm{mAb}$ therapies over the standard $\mathrm{R}-\mathrm{CHOP}$ regimen [99]. Hence, a strong rationale exists for examining the roles of $\mathrm{CD} 20-\mathrm{ADCs}$ rather than CD20-mAbs in clinical applications. 


\section{MT-3724}

MT-3724 is an innovative engineered anti-CD20 ADC that contains a variable fragment (scFv) bonded to Shigalike toxin-1A (SLTA), which expedites both internalization and cell killing by ribosomal inhibition. The results of a phase I trial (NCT02361346) of MT-3724 monotherapy demonstrated clinical anti-neoplastic activity in heavily pretreated R/R B-NHL patients, especially in the advanced-stage DLBCL subset with an ORR of 30\% [100]. The most common AEs related to the drug were edema (67\%), fatigue (43\%), diarrhea (38\%), myalgia (38\%), and cough (33\%). To estimate the feasibility of combining MT-3724 with chemotherapies or immunomodulatory agents, MT-3724 was tested in combination with Len, revealing potentiated cytotoxicity in CD20-positive cell lines and supporting the further assessment of MT-3724 in a phase II trial in combination with Len in adult patients with R/R NHL [101].

\section{Anti-CD25 ADCs}

CD25 is the $\alpha$ subunit of the IL-2 receptor (IL-2R $\alpha$ ) and can increase the affinity of ligand binding and active oncogenic signaling pathways [102]. Indeed, upregulated CD25 expression is related to a more aggressive course and an inferior outcome in DLBCL, FL, HL, and CLL [103-106]. It has also been shown to promote lymphomagenesis and drug resistance in T cell lymphomas [107].

\section{Camidanlumab tesirine}

Camidanlumab tesirine (ADCT-301) is an ADC comprising human IgG1 that is stochastically coupled with a protease-cleavable linker and has a PBD dimer as its payload [108]. The drug was evaluated in R/R NHL and R/R $\mathrm{cHL}$ in a phase I trial (NCT02432235), showing a promising antitumor activity profile, especially $\mathrm{cHL}$ and the $\mathrm{T}$ cell lymphoma subtype $[108,109]$. In the cHL group, the ORR was $69 \%$, with $44 \%$ CR. Moreover, the ORR and CR rate were $81 \%$ and $50 \%$, respectively, in a population of 26 heavily pretreated patients in the $45 \mu \mathrm{g} / \mathrm{kg}$ dose group. The trial also reported a superior ORR of $50 \%$ in the $\mathrm{T}$ cell lymphoma subgroup versus an ORR of $31 \%$ in the B cell lymphoma subgroup. Further analysis based on prior therapies showed an ORR of $81 \%$ for patients with CHL who previously received BV. The median DOR and PFS were 7.7 and 6.7 months in the cHL group, respectively. Common TEAEs comprised fatigue (42\%), rash (33\%), liver abnormality (30\%), and pyrexia (30\%), and $16(27 \%)$ cases of peripheral edema or effusion were also noted. Although it is still under investigation, ADCT-301 may be a potential therapeutic option for patients with $\mathrm{HL}$ after failure to BV.

\section{Anti-CD30 ADCs}

Anti-CD30-LDM, an innovative ADC with an intact antiCD30 antibody conjugated to LDM via a non-cleavable linker, presents attractive tumor-targeting capability and antitumor efficacy both in vitro and in vivo [110]. Treatment with anti-CD30-LDM remarkably inhibited tumor growth in mice in a dose-dependent manner without apparent AEs. Anti-CD30-LDM exerts its cytotoxic effects by inducing DNA damage instead of by blocking the polymerization of tubulin, highlighting its potential for overcoming resistance induced by BV. Additionally, anti-CD30-LDM augmented programmed cell death-1 ligand 1 (PD-L1) presentation in cell lines, indicating possible antitumor synergy between anti-CD30-LDM and immunotherapy agents. Consequently, it could be chosen for further testing as a single agent or combination therapy.

\section{Anti-CD37 ADCs}

CD37 is a member of the tetra-spanning superfamily, which directly mediates survival and apoptotic signaling, and is expressed on normal and malignant mature B cells, similar to CD20. CD37 has been introduced as an appealing target for treating DLBCL because the expression level of CD37 on neoplastic cells in patients with DLBCL correlates with PFS and OS [111]. To date, the development of anti-CD37 ADCs has shown limited progression due to limited clinical efficacy.

\section{Naratuximab emtansine}

Naratuximab emtansine (also known as IMGN529) is a CD37-directed ADC consisting of a humanized IgG1 mAb linked to DM1 via succinimidyl-4-(Nmaleimidomethyl)-cyclohexane-1-carboxylate (SMCC), a thioether linker [112]. A pivotal phase I trial reported that the MTD and RP2D of IMGN529 were $1.4 \mathrm{mg} / \mathrm{kg}$ and $0.7 \mathrm{mg} / \mathrm{kg}$, respectively, in adult patients with $\mathrm{R} / \mathrm{R}$ B-NHL [113]. Among 39 response-evaluable patients, the efficacy was limited, with an ORR of $13 \%$ (1 CR and 4 PRs, 4 of which occurred in the DLBCL subset). The most frequent TEAEs were fatigue (39\%), neutropenia (37\%), thrombocytopenia (37\%), and pyrexia (37\%). Additional preclinical studies revealed that the combination of IMGN529 with rituximab had potentially enhanced antitumor efficacy compared with either single agent [114]. At present, a phase II trial (NCT02564744) is ongoing to investigate the combination of these two agents in a larger cohort.

\section{AGS67E}

A humanized anti-CD37 IgG2 mAb binds to MMAE via a protease-cleavable linker, and the resulting $A D C$, AGS67E, retains the inherent antibody activities. The 
intrinsic effects of AGS67E include direct proapoptotic activity and potent cytotoxicity, leading to cell death in several types of NHL and AML cell lines [115]. First, a phase I trial (NCT02175433) described a moderate response in terms of an ORR of $22 \%$ and CR rate of $14 \%$ in 50 patients with R/R B-NHL and R/R T-NHL, and a small number of patients experienced PN $(16 \%)$ and neutropenia (8\%) [116]. One ongoing, multicenter phase I study enrolled 30 participants who had received at least two prior systemic therapies treated with AGS67E and determined the MTD with or without G-CSF [117]. Specifically, the preliminary results reported that two subjects with DLBCL achieved a CR, and two subjects (one with MF and one with DLBCL) achieved a PR. The neutropenia that occurred in the trial may largely be attributed to the bystander effect, and G-CSF administration appeared to significantly improve the recovery rate [118]. Expansion cohorts are planned at the MTD with or without G-CSF.

\section{Anti-CD70 ADCs}

CD70 is a member of the TNF receptor superfamily and acts as a functional receptor binding to soluble CD27. CD70 is expressed on some types of lymphomas and solid tumors, where it correlates with poor prognosis $[119,120]$. Three anti-CD70 ADCs had reached phase I clinical development in patients with CD70-positive R/R B-NHL and metastatic renal cell carcinoma (RCC). Unfortunately, none of these ADCs was retained for further evaluation due to a lack of clinical benefit and excess toxicity.

SGN-CD70A, an ADC, contains an antibody against CD70 linked to the PBD dimer via a protease-cleavable linker. A first-in-human phase I study described early-onset severe side effects and undesirable efficacy in patients with $\mathrm{R} / \mathrm{R}$ CD70-positive NHL, including DLBCL, MCL, and grade 3b FL [121]. The application of SGN-CD70A has been limited due to the occurrence of grade 4 thrombocytopenia, albeit with long-lasting remission. MDX-1203 (BMS-936561) comprises a fully human IgG1 antibody specific for CD70 linked through a protease-cleavable linker attached to a duocarmycin derivative. The dose-escalation phase I trial was discontinued on account of limited antitumor activity for patients who received more than three prior systemic administrations [122]. Vorsetuzumab mafodotin (SGN75 ) is a humanized anti-CD70 ADC with an IgG1 mAb, MMAF payload, and a non-cleavable linker. Given its unacceptable toxicity (idiopathic thrombocytopenic purpura), a phase I study in patients with R/R CD70-positive NHL or metastatic RCC was terminated [123]. Considering that alleviating thrombocytopenia is currently not possible, the applicability of CD70-targeting ADCs remains limited.

\section{Anti-CD74 ADCs}

CD74 is a type II transmembrane glycoprotein that is involved in the presentation of endogenous antigens and the process of immune regulation. The expression of CD74 protein is found in a wide variety of normal tissues and lymphoid malignancies, supporting the application of anti-CD74 antibodies for targeted immunomodulatory therapies [124].

Only 2 CD74-targeting ADCs (STRO-001 and hLL1DOX) have reached clinical development. STRO-001 is a humanized and glycosylated anti-CD74 ADC that is generated by novel cell-free protein synthesis technology and integrates a non-cleavable linker and maytansinoid payload. It exhibits a high degree of homogeneity and stability because of its site-specific conjugation. Preliminary data from an open-label phase I study (NCT03424603) of STRO-001 in heavily pretreated patients with advanced $B$ cell malignancies provided early signs of efficacy and a good safety profile [125]. The ORR was $25 \%$ in 16 evaluable patients with no ocular or neuropathy disorders observed. The study recently began to dose patients at planned levels of $2.5 \mathrm{mg} / \mathrm{kg}$ and $3.5 \mathrm{mg} / \mathrm{kg}$. Milatuzumab doxorubicin (hLL1-DOX) was also explored in a phase I/ II trial (NCT01585688) of patients with R/R B-NHL or CLL, but unsatisfactory results led to trial discontinuation [126]. SP7676, another anti-CD74 ADC, has a high degree of stability in circulation via site-specific conjugation. It elicits a strong response, as evidenced by $100 \%$ of animals achieving complete regression of tumors in lymphoma models, and SP7676 achieved the intended pharmacodynamic effect and produced tumor regression in the "double-hit" lymphoma models [127]. Nevertheless, the development of these drugs is still in the early stage, and further exploration is needed to ascertain their value in clinical applications.

\section{Anti-CD79b ADCs \\ Iladatuzumab vedotin}

In addition to Pola, iladatuzumab vedotin (DCDS0780A), another $\mathrm{ADC}$ directed against $\mathrm{CD} 79 \mathrm{~b}$ featuring a protease-cleavable linker and MMAE payload, has been introduced. A first-in-human phase I trial (NCT02453087) recently described the preliminary outcomes of iladatuzumab vedotin alone or in combination with rituximab in patients with R/R B-NHL or CLL. One primary endpoint, improvement in ORR, was not satisfactorily met because the ORR was only slightly greater for the rituximab combination group ( $85 \%$ vs. $84 \%)$ [128]. Among all patients with DLBCL $(n=24)$, the ORR was $60 \%(43 \% \mathrm{CR})$. In a pooled patient population, $43 \%$ 
experienced ocular disorders leading to dose reduction or drug interruption, and $22 \%$ experienced neutropenia (grade $\geq 3$ ). The unsatisfactory results and ocular toxicity observed have hindered the progress of iladatuzumab vedotin into phase II trials.

\section{Anti-ROR1 ADCs}

ROR1 is an oncofetal glycoprotein expressed on CLL, MCL, a variety of malignant tumors, and early-stage $B$ cells but is rarely expressed in normal adult tissues. Moreover, a high level of ROR1 expression in cancer cells appears to be involved in the inhibition of apoptosis and predicts an inferior outcome in primary refractory DLBCL, low-grade FL, and Richter's syndrome [129].

\section{VLS-101}

VLS-101, an innovative ADC, comprises a UC-961 linker, MMAE, and an anti-ROR1 receptor. VLS-101 caused almost complete tumor regression, which was observed even in models without universal ROR1 expression, suggesting MMAE bystander killing [130]. It also induced a long-term response and considerably extended survival after treatment discontinuation. A phase I clinical trial (NCT03833180) of VLS-101 investigated patients who failed a median of 4 prior systemic therapies with MCL $(n=15)$, CLL $(n=7)$, DLBCL $(n=5)$, FL $(n=3)$, or MZL $(n=1)[131,132]$. The reported ORR was $47 \%$, with $20 \%$ of MCL patients achieving a CR. In the DLBCL subgroup, an ORR of $80 \%(40 \% \mathrm{CR})$ was seen in 5 patients. Among 15 patients with R/R MCL, 100\% of patients received BTK inhibitors, including $87 \%$ of patients who progressed on BTK inhibitors. Grade 4 neutropenia occurred in $28 \%$ of patients, with $3 \%$ of patients having neutropenic fever. Considering the data above, VLS101 had signs of potential clinical benefits in aggressive DLBCL or MCL with tolerable side effects in the study. Phase I/II studies of VLS-101 monotherapy and combination therapy in patients with hematological tumors are currently under investigation.

\section{Cirmtuzumab-ADC-7}

Cirmtuzumab-ADC-7, another ADC including a humanized IgG1 mAb and a cirmtuzumab (UC-961)-linker connecting MMAE, was selected for further testing in CLL and MCL cell lines because it was well tolerated with high stability and signs of efficacy in preclinical studies [133]. In addition, drugs such as ibrutinib that inhibit the BCR pathway can impair ROR1 expression and consequently ROR1-targeting treatments, suggesting a potential role for investigating combination therapeutics [134]. Cirmtuzumab-ADC-7 plus venetoclax (a BCL2 antagonist) caused almost complete regression of tumors in xenograft models, indicating the potent synergistic cytotoxicity of combining these two agents. Taken together, cirmtuzumab-based ADCs have promise and warrant further investigation for the treatment of patients with ROR1-positive malignancies.

\section{ADCs targeting other antigens}

ADCs under preclinical exploration and demonstrating activity in animal models of lymphomas include those targeting several antigens that have not been described in the aforementioned parts (CD38, CD123, CD185, CD205, and HLA-DR) (Table 2).

\section{Future perspectives}

In the modern era, ADCs in combination with other potent antitumor drugs have been proposed to achieve a durable response and to broaden the therapeutic window of combination agents. Based on the encouraging outcomes of several clinical trials, studies on ADCs have assessed their roles in the first-line, consolidation, and salvage settings. Notably, combination treatment, such as ADCs in combination with immune checkpoint blockades, may provide synergistic clinical activity. However,

Table 2 Preclinical antibody-drug conjugates active in animal models of lymphoma

\begin{tabular}{lllll}
\hline Agent & Target & Linker & Payload & Indication \\
\hline huB4-DGN462 & CD19 & Sulfo-SPDB & DGN462 & B cell lymphoma [150] \\
RC58-based ADC & CD19 & Maleimide-PEG-based linkers & $/$ & B cell lymphoma [151] \\
Anti-CD30-LDM & CD30 & Non-cleavable linker & LDM & HL and ALCL [110] \\
CD38-077 & CD38 & Non-polyethylene glycol linker & Duostatin 5.2 & Burkitt's lymphoma and MM [152] \\
BAY-943 (IL3RA-ADC) & CD123 & Protease-cleavable linker & KSP inhibitor & AML and HL [153] \\
BAY 924 & CD185 & $/$ & KSP inhibitor & B cell lymphoma [154] \\
MEN1309/OBT076 & CD205 & SPDB & DM4 & B cell lymphoma [155] \\
IMMU-140 & HLA-DR & Cleavable linker & SN-38 & HL, NHL and CLL [156] \\
\hline
\end{tabular}

ALCL, anaplastic large cell lymphoma; $\mathrm{HL}$, Hodgkin lymphoma; $\mathrm{MM}$, multiple myeloma; $\mathrm{AML}$, acute myeloid leukemia; $\mathrm{NHL}$, non-Hodgkin lymphoma; $\mathrm{CLL}$, chronic lymphocytic leukemia; KSP, kinesin spindle protein 
accompanying toxicity may occur [135-138]. To improve the response rates, it is important to select novel targets that are exclusively expressed on cancer cells. Progress has been achieved in designing novel antibody formats to optimize the stability and DAR of ADCs, which may facilitate tumor uptake. Efforts have also been made to apply novel kinds of linkers in ADCs to augment the bystander effect and thereby target heterogeneous tumors or cancers with homogeneous but low target expression. Given the accumulation of many incremental advances in technology, such as site-specific conjugation approaches, the generation of highly efficacious and less toxic ADCs has become possible.

When patients show undesirable responses or are insensitive to ADCs, opportunities also exist to innovate in ADC payloads, moving beyond typical cytotoxic drugs to immunotherapeutic agents rationally chosen for their antitumor activity. Novel ADCs may employ NAMPT inhibitors as a new nonantimitotic payload targeting $\mathrm{T}$ cell lymphomas [139]. It is worth noting that ZW38 is a novel bispecific ADC engineered to induce increased response rates, reduce the incidence of relapse, and ameliorate the therapeutic index [140].

Likewise, advances in biological platforms have paved the way to expanding the possibilities for ADC development. For example, THIOMAB, a novel cysteine engineered technology, was proposed to optimize the bioconjugation efficiency and allow the generation of more stable and efficacious ADCs with controlled DARs, thereby generating less toxic ADCs [141, 142]. A highthroughput conjugation strategy was developed for THIOMAB antibodies to identify the sites suitable for linking to auristatin derivatives [143]. Additionally, cell-free protein synthesis has emerged as an attractive candidate to produce more homogenous ADCs by introducing payloads at one or more defined sites, thus developing more stable and less toxic ADCs [144]. A gene engineering technology, the CRISPR/Cas-9 system, offers the opportunity to engineer Fab molecules and allows for dual sitespecific conjugation without compromising target affinity [145]. Harnessing the platform to produce Fab fragments and be equipped with two distinct cytotoxic payloads appears to be a promising option to obtain a better therapeutic outcome while reducing the toxicity of the combination therapy.

The expanding repertoire of applicable ADCs in the clinic has also raised interest in the issue of ADC resistance. Studies to date have implied some potentially causative factors, including downregulation of the antigen, mutation of the antigen, overexpression of drug transporters, variations in ADC distribution, and alteration of the lysosomal environment [146]. One study revealed that acquired resistance to PBD dimer-containing ADCs may be attributed to specific ATP-binding cassette drug transporters, which may guide decision-making in drug combination strategies [147]. Further investigation could focus on non-internalizing ADCs targeting the tumor microenvironment to avoid ADC resistance. Moreover, new technologies such as single-cell sequencing could be used in the development of more accurate biomarker assessments that can avoid the interference of tumor heterogeneity and contribute to overcoming drug resistance $[148,149]$.

\section{Conclusion}

ADCs are a promising treatment that has risen to prominence over the past three decades. Antibodies, linkers, and payloads, every aspect of ADCs, are evolving dramatically and will be fundamental to optimizing the design and further development of this therapeutic class. Newly developed ADCs are more strategically designed compounds and benefit from improvements in tumor specificity, off-target toxicity, and payload potency. "Old" challenges, such as drug resistance, will probably be resolved by lymphoma therapeutics leveraging ADCs in combination with other agents. With the emergence of enormous numbers of combinatorial approaches, there is an urgent need for robust phase I testing to ensure manageable toxicity and plan feasible combination-dosing regimens. In addition, innovative biomarker measurements and appropriate patient selection strategies will pave the way for ADC development.

\section{Abbreviations}

ADC: Antibody-drug conjugate; mAb: Monoclonal antibody; IgG: Immunoglobulin G; ADCC: Antibody-dependent cytotoxicity; ADCP: Antibodydependent cell-mediated phagocytosis; DAR: Drug-to-antibody ratio; PBD: Pyrrolobenzodiazepine; MMAE: Monomethyl auristatin E; MMAF: Monomethyl auristatin F; DLT: Dose-limiting toxicity; DM1: N20-deacetyl-N20-(3-mercapto1-oxopropyl)-maytansine; DM4: N20-deacetyl-N20-(4-mercapto-4-methyl1-oxopentyl)-maytansine; NHL: Non-Hodgkin lymphoma; KSP: Kinesin spindle protein; SPDB: N-Succinimidyl-4-(2-pyridylthio)-butanoate; SPP: N-Succinimidyl-4-(2-pyridyldithio)-pentanoate; Ala: Alanine; Cit: Citrulline; Val: Valine; MC: Maleimidocaproyl; SMCC: Succinimidyl-4-(N-maleimidomethyl)cyclohexane-1-carboxylate; BV: Brentuximab vedotin; Pola: Polatuzumab vedotin; Pina: Pinatuzumab vedotin; HL: Hodgkin lymphoma; CHL: Classical Hodgkin lymphoma; ALCL: Anaplastic large cell lymphoma; PMBCL: Primary mediastinal B cell lymphoma; ASCT: Autologous stem cell transplantation; HSCT: Hematopoietic stem cell transplantation; Len: Lenalidomide; Nivo: Nivolumab; ORR: Overall response rate; CR: Complete response; PR: Partial response; OS: Overall survival; PFS: Progression-free survival; R/R: Relapsed or refractory; AE: Adverse event; PN: Peripheral neuropathy; PTCL: Peripheral T cell lymphoma; CTCL: Cutaneous T cell lymphoma; DLBCL: Diffuse large B cell lymphoma; DOR: Duration of response; FL: Follicular lymphoma; MCL: Mantle cell lymphoma; G-CSF: Granulocyte colony stimulating factor; TEAE: Treatment-emergent adverse event; RP2D: Recommended phase II dose; MTD: Maximum-tolerated dose.

Acknowledgements

Not applicable 


\section{Authors' contributions}

Y.C. wrote and edited this manuscript and created figures and tables. X.Z. and X.W. reviewed and revised the manuscript. X.W. provided direction and guidance throughout the preparation of the manuscript. All authors read and approved the final manuscript.

\section{Funding}

This study was supported by National Natural Science Foundation (No.81800194, No.82070203, No.81770210, No.81473486 and No.81270598): Key Research and Development Program of Shandong Province (No.2018CXGC1213); Development Project of Youth Innovation Teams in Colleges and Universities of Shandong Province (No.2020KJL006); China Postdoctoral Science Foundation (No.2020M672103); Technology Development Projects of Shandong Province (No.2017GSF18189); Translational Research Grant of NCRCH (No.2021WWB02, No.2020ZKMB01); Shandong Provincial Natural Science Foundation (No. ZR2018BH011); Technology Development Project of Jinan City (No. 201805065); Taishan Scholars Program of Shandong Province; Shandong Provincial Engineering Research Center of Lymphoma; Academic Promotion Programme of Shandong First Medical University (No. 2019QL018, No. 2020RC006).

\section{Availability of data and materials}

Not applicable.

\section{Declarations}

\section{Ethics approval and consent to participate}

Not applicable.

\section{Consent for publication}

Not applicable.

\section{Competing interests}

The authors declare that they have no competing interests.

\section{Author details}

${ }^{1}$ Department of Hematology, Shandong Provincial Hospital, Cheeloo College of Medicine, Shandong University, No.324, Jingwu Road, Jinan 250021, Shandong, China. ${ }^{2}$ Department of Hematology, Shandong Provincial Hospital Affiliated to Shandong First Medical University, Jinan 250021, Shandong, China. ${ }^{3}$ School of Medicine, Shandong University, Jinan 250012, Shandong, China. ${ }^{4}$ Shandong Provincial Engineering Research Center of Lymphoma, Jinan 250021, Shandong, China. ${ }^{5}$ Branch of National Clinical Research Center for Hematologic Diseases, Jinan 250021, Shandong, China. ${ }^{6}$ National Clinical Research Center for Hematologic Diseases, the First Affiliated Hospital of Soochow University, Suzhou 251006, China.

\section{Received: 4 March 2021 Accepted: 24 May 2021}

Published online: 05 June 2021

\section{References}

1. Le Gouill S, Thieblemont C, Oberic L, Moreau A, Bouabdallah K, Dartigeas C, Damaj G, Gastinne T, Ribrag V, Feugier P, Casasnovas O, Zerazhi H, Haioun C, Maisonneuve H, Houot R, Jardin F, Van den Neste E, Tournilhac O, Le Du K, Morschhauser F, Cartron G, Fornecker LM, Canioni D, Callanan M, Bene MC, Salles G, Tilly H, Lamy T, Gressin R, Hermine $\mathrm{O}$, et al. Rituximab after autologous stem-cell transplantation in mantle-cell lymphoma. N Engl J Med. 2017;377(13):1250-60.

2. Marcus R, Davies A, Ando K, Klapper W, Opat S, Owen C, Phillips E, Sangha R, Schlag R, Seymour JF, Townsend W, Trneny M, Wenger M, Fingerle-Rowson G, Rufibach K, Moore T, Herold M, Hiddemann W. Obinutuzumab for the first-line treatment of follicular lymphoma. N Engl J Med. 2017;377(14):1331-44.

3. Thielen FW, Buyukkaramikli NC, Riemsma R, Fayter D, Armstrong N, Wei CY, Huertas Carrera V, Misso K, Worthy G, Kleijnen J, Corro Ramos I. Obinutuzumab in combination with chemotherapy for the first-line treatment of patients with advanced follicular lymphoma: an evidence review group evaluation of the NICE single technology appraisal. Pharmacoeconomics. 2019;37(8):975-84.

4. Goy A, Ramchandren R, Ghosh N, Munoz J, Morgan DS, Dang NH, Knapp M, Delioukina M, Kingsley E, Ping J, Beaupre DM, Neuenburg JK, Ruan J. Ibrutinib plus lenalidomide and rituximab has promising activity in relapsed/refractory non-germinal center B-cell-like DLBCL. Blood. 2019:134(13):1024-36.

5. Staudacher AH, Brown MP. Antibody drug conjugates and bystander killing: is antigen-dependent internalisation required? $\mathrm{Br} J$ Cancer. 2017;117(12):1736-42.

6. Tolcher AW. Antibody drug conjugates: lessons from 20 years of clinical experience. Ann Oncol. 2016;27(12):2168-72.

7. Zinzani PL, Santoro A, Gritti G, Brice P, Barr PM, Kuruvilla J, Cunningham D, Kline J, Johnson NA, Mehta-Shah N, Manley T, Francis S, Sharma M, Moskowitz AJ. Nivolumab combined with brentuximab vedotin for relapsed/refractory primary mediastinal large B-cell lymphoma: efficacy and safety from the phase II CheckMate 436 study. J Clin Oncol. 2019;37(33):3081-9.

8. Garcia-Sanz R, Sureda A, de la Cruz F, Canales M, Gonzalez AP, Pinana JL, Rodriguez A, Gutierrez A, Domingo-Domenech E, Sanchez-Gonzalez B, Rodriguez G, Lopez J, Moreno M, Rodriguez-Salazar MJ, JimenezCabrera S, Caballero MD, Martinez C. Brentuximab vedotin and ESHAP is highly effective as second-line therapy for Hodgkin lymphoma patients (long-term results of a trial by the Spanish GELTAMO Group). Ann Oncol. 2019:30(4):612-20.

9. Burke JM, Morschhauser F, Andorsky D, Lee C, Sharman JP. Antibodydrug conjugates for previously treated aggressive lymphomas: focus on polatuzumab vedotin. Exp Rev Clin Pharmacol. 2020;13(10):1073-83.

10. Bourbon E, Salles G. Polatuzumab vedotin: an investigational antiCD79b antibody drug conjugate for the treatment of diffuse large B-cell lymphoma. Exp Opin Investig Drugs. 2020:29(10):1079-88.

11. Kovtun YV, Audette CA, Ye YM, Xie HS, Ruberti MF, Phinney SJ, Leece BA, Chittenden T, Blattler WA, Goldmacher VS. Antibody-drug conjugates designed to eradicate tumors with homogeneous and heterogeneous expression of the target antigen. Can Res. 2006;66(6):3214-21.

12. Yu JF, Song YP, Tian WZ. How to select IgG subclasses in developing anti-tumor therapeutic antibodies. J Hematol Oncol. 2020;13(1):10.

13. Vidarsson G, Dekkers G, Rispens T. IgG subclasses and allotypes: from structure to effector functions. Front Immunol. 2014;5:17.

14. Beck A, Goetsch L, Dumontet C, Corvaia N. Strategies and challenges for the next generation of antibody drug conjugates. Nat Rev Drug Discov. 2017:16(5):315-37.

15. Schmidt MM, Wittrup KD. A modeling analysis of the effects of molecular size and binding affinity on tumor targeting. Mol Cancer Ther. 2009;8(10):2861-71.

16. Merten H, Brandl F, Plueckthun A, Zangemeister-Wittke U. Antibodydrug conjugates for tumor targeting-novel conjugation chemistries and the promise of non-lgG binding proteins. Bioconjug Chem. 2015:26(11):2176-85.

17. Moh ESX, Sayyadi N, Packer NH. Chemoenzymatic glycan labelling as a platform for site-specific IgM-antibody drug conjugates. Anal Biochem. 2019;584:7.

18. Hwang D, Rader C. Site-specific antibody-drug conjugates in triple variable domain Fab format. Biomolecules. 2020;10(5):12.

19. DiJoseph JF, Dougher MM, Armellino DC, Kalyandrug L, Kunz A, Boghaert ER, Hamann PR, Damle NK. CD20-specific antibodytargeted chemotherapy of non-Hodgkin's B-cell lymphoma using calicheamicin-conjugated rituximab. Cancer Immunol Immunother 2007;56(7):1107-17.

20. Bernt KM, Prokop A, Huebener N, Gaedicke G, Wrasidlo W, Lode HN. Eradication of CD19(+) Leukemia by targeted Calicheamicin theta. Bioconjug Chem. 2009;20(8):1587-94.

21. Yu B, Liu DL. Antibody-drug conjugates in clinical trials for lymphoid malignancies and multiple myeloma. J Hematol Oncol. 2019;12(1):17.

22. Zammarchi F, Corbett S, Adams L, Tyrer PC, Kiakos K, Janghra N, Marafioti T, Britten CE, Havenith CEG, Chivers S, D'Hooge F, Williams DG, Tiberghien A, Howard PW, Hartley JA, van Berkel PH. ADCT-402, a PBD dimer-containing antibody drug conjugate targeting CD19-expressing malignancies. Blood. 2018;131(10):1094-105.

23. Flynn MJ, Zammarchi F, Tyrer PC, Akarca AU, Janghra N, Britten CE, Havenith CEG, Levy J-N, Tiberghien A, Masterson LA, Barry C, D'Hooge 
F, Marafioti T, Parren PWHI, Williams DG, Howard PW, van Berkel PH, Hartley JA. ADCT-301, a pyrrolobenzodiazepine (PBD) dimer-containing antibody-drug conjugate (ADC) targeting CD25-expressing hematological malignancies. Mol Cancer Ther. 2016;15(11):2709-21.

24. Camus V, Tilly H. Polatuzumab vedotin, an anti-CD79b antibody-drug conjugate for the treatment of relapsed/refractory diffuse large B-cell lymphoma. Future Oncol. 2020;17(2):127-36.

25. Sehn LH, Herrera AF, Flowers CR, Kamdar MK, McMillan A, Hertzberg M, Assouline S, Kim TM, Kim WS, Ozcan M, Hirata J, Penuel E, Paulson JN, Cheng J, Ku G, Matasar MJ. Polatuzumab vedotin in relapsed or refractory diffuse large B-cell lymphoma. J Clin Oncol. 2020;38(2):155-65.

26. Wolska-Washer A, Robak P, Smolewski P, Robak T. Emerging antibodydrug conjugates for treating lymphoid malignancies. Exp Opin Emerg Drugs. 2017;22(3):259-73.

27. Li F, Emmerton KK, Jonas M, Zhang X, Miyamoto JB, Setter JR, Nicholas ND, Okeley NM, Lyon RP, Benjamin DR, Law CL. Intracellular released payload influences potency and bystander-killing effects of antibodydrug conjugates in preclinical models. Cancer Res. 2016;76(9):2710-9.

28. Polson AG, Williams M, Gray AM, Fuji RN, Poon KA, McBride J, Raab H, Januario T, Go M, Lau J, Yu SF, Du C, Fuh F, Tan C, Wu Y, Liang WC, Prabhu S, Stephan JP, Hongo JA, Dere RC, Deng R, Cullen M, de Tute R, Bennett F, Rawstron A, Jack A, Ebens A. Anti-CD22-MCC-DM1: an antibodydrug conjugate with a stable linker for the treatment of non-Hodgkin's lymphoma. Leukemia. 2010;24(9):1566-73.

29. Hong EE, Erickson H, Lutz RJ, Whiteman KR, Jones G, Kovtun Y, Blanc V, Lambert JM. Design of coltuximab ravtansine, a CD19-targeting antibody drug conjugate (ADC) for the treatment of B-cell malignancies: structure-activity relationships and preclinical evaluation. Mol Pharm. 2015;12(6):1703-16

30. Moore KN, Martin LP, O'Malley DM, Matulonis UA, Konner JA, Perez RP, Bauer TM, Ruiz-Soto R, Birrer MJ. Safety and activity of mirvetuximab soravtansine (IMGN853), a Folate receptor alpha-targeting antibody-drug conjugate, in platinum-resistant ovarian, fallopian tube, or primary peritoneal cancer: a phase i expansion study. J Clin Oncol. 2017:35(10):1112-8.

31. Fu Y, Ho M. DNA damaging agent-based antibody-drug conjugates for cancer therapy. Antibody Therap. 2018;1 (2):33-43.

32. Polson AG, Zheng B, Go M, Lau J, Yu SF, Spencer S, Cohen R, Caruso M, Flygare J, Polakis P. Anthracycline based antibody-drug conjugates (ADCs) for the treatment of non-Hodgkin's lymphoma are effective in cell lines resistant to auristatin based ADCs. Can Res. 2013;73(Suppl 1):4634.

33. Mantaj J, Jackson PJM, Rahman KM, Thurston DE. From anthramycin to pyrrolobenzodiazepine (PBD)-containing antibody-drug conjugates (ADCs). Angew Chem Int Ed. 2017;56(2):462-88.

34. Miller ML, Shizuka M, Wilhelm A, Salomon P, Reid EE, Lanieri L, Sikka S, Maloney EK, Harvey L, Qiu Q, Archer KE, Bai C, Vitharana D, Harris L, Singh R, Ponte JF, Yoder NC, Kovtun Y, Lai KC, Ab O, Pinkas J, Keating TA, Chari RVJ. A DNA-interacting payload designed to eliminate crosslinking improves the therapeutic index of antibody-drug conjugates (ADCs). Mol Cancer Ther. 2018;17(3):650-60.

35. Yu S-F, Lee DW, Zheng B, Del Rosario G, Leipold D, Booler H, Zhong F, Carrasco-Triguero M, Hong K, Yan P, Rowntree RK, Schutten MM, Pillow T, Sadowsky JD, Dragovich PS, Polson AG. An Anti-CD22-seco-CBI-dimer antibody-drug conjugate (ADC) for the treatment of non-Hodgkin lymphoma that provides a longer duration of response than Auristatinbased ADCs in preclinical models. Mol Cancer Ther. 2021;20(2):340-6.

36. Gebleux R, Stringhini M, Casanova R, Soltermann A, Neri D. Non-internalizing antibody-drug conjugates display potent anti-cancer activity upon proteolytic release of monomethyl auristatin $\mathrm{E}$ in the subendothelial extracellular matrix. Int J Cancer. 2017;140(7):1670-9.

37. Walsh SJ, Bargh JD, Dannheim FM, Hanby AR, Seki H, Counsell AJ, Ou X, Fowler E, Ashman N, Takada Y, Isidro-Llobet A, Parker JS, Carroll JS, Spring DR. Site-selective modification strategies in antibody-drug conjugates. Chem Soc Rev. 2021;50(2):1305-53.

38. Dennler P, Chiotellis A, Fischer E, Bregeon D, Belmant C, Gauthier L, Lhospice F, Romagne F, Schibli R. Transglutaminase-based chemoenzymatic conjugation approach yields homogeneous antibody-drug conjugates. Bioconjug Chem. 2014;25(3):569-78.

39. Krzyscik MA, Opalinski L, Otlewski J. Novel method for preparation of site-specific, stoichiometric-controlled dual warhead conjugate of FGF2 via dimerization employing sortase A-mediated ligation. Mol Pharm. 2019;16(8):3588-99.

40. Faridoon SW, Qin K, Tang Y, Li M, Guan D, Tian X, Jiang B, Dong J, Tang F, Huang W. New linker structures applied in glycosite-specific antibody drug conjugates. Organ Chem Fron. 2019;6(17):3144-9.

41. Rabuka D, Rush JS, deHart GW, Wu P, Bertozzi CR. Site-specific chemical protein conjugation using genetically encoded aldehyde tags. Nat Protoc. 2012;7(6):1052-67.

42. Xu Y, Jin S, Zhao W, Liu W, Ding D, Zhou J, Chen S. A versatile chemoenzymatic conjugation approach yields homogeneous and highly potent antibody-drug conjugates. Int J Mol Sci. 2017;18(11):2284.

43. Kumar A, Kinneer K, Masterson L, Ezeadi E, Howard P, Wu H, Gao C, Dimasi N. Synthesis of a heterotrifunctional linker for the site-specific preparation of antibody-drug conjugates with two distinct warheads. Bioorg Med Chem Lett. 2018;28(23-24):3617-21.

44. Nilchan N, Li X, Pedzisa L, Nanna AR, Roush WR, Rader C. Dual-mechanistic antibody-drug conjugate via site-specific selenocysteine/cysteine conjugation. Antibody Therap. 2019;2(4):71-8.

45. Deutsch YE, Tadmor T, Podack ER, Rosenblatt JD. CD30: an important new target in hematologic malignancies. Leuk Lymphoma. 2011;52(9):1641-54

46. Kampa F, Mitteldorf C. A review of CD30 expression in cutaneous neoplasms. J Cutan Pathol. 2021;48(4):495-510.

47. de Claro RA, McGinn K, Kwitkowski V, Bullock J, Khandelwal A, Habtemariam B, Ouyang Y, Saber H, Lee K, Koti K, Rothmann M, Shapiro M, Borrego F, Clouse K, Chen XH, Brown J, Akinsanya L, Kane R, Kaminskas E, Farrell A, Pazdur R. US food and drug administration approval summary: brentuximab vedotin for the treatment of relapsed Hodgkin Lymphoma or Relapsed Systemic Anaplastic Large-Cell Lymphoma. Clin Cancer Res. 2012;18(21):5845-9.

48. Younes A, Gopal AK, Smith SE, Ansell SM, Rosenblatt JD, Savage KJ, Ramchandren R, Bartlett NL, Cheson BD, de Vos S, Forero-Torres A, Moskowitz CH, Connors JM, Engert A, Larsen EK, Kennedy DA, Sievers EL, Chen R. Results of a pivotal phase II study of brentuximab vedotin for patients with relapsed or refractory Hodgkin's lymphoma. J Clin Oncol. 2012;30(18):2183-9.

49. Kuruvilla J, Ramchandren R, Santoro A, Paszkiewicz-Kozik E, Gasiorowski R, Johnson NA, Fogliatto LM, Goncalves I, de Oliveira J, Buccheri V, Perini GF, Goldschmidt N, Kryachok I, Sekiguchi N, Lin J, Nahar A, Marinello P, Zinzani PL. Effect of pembrolizumab (pembro) monotherapy versus brentuximab vedotin (BV) on patients (Pts) with relapsed/refractory classical Hodgkin lymphoma (R/R cHL): exploratory analysis of the randomized, phase 3 keynote-204 study by prior lines of therapy. Blood. 2020;136(Suppl 1):12.

50. Wei W, Lin Y, Song Z, Xiao W, Chen L, Yin J, Zhou Y, Barta SK, Petrus M, Waldmann TA, Yang Y. A20 and RBX1 regulate brentuximab vedotin sensitivity in Hodgkin lymphoma models. Clin Cancer Res Off J Am Assoc Cancer Res. 2020;26(15):4093-106.

51. Chen R, Herrera A, Hou J, Chen L, Wu J, Guo Y, Synold TW, Ngo VN, Puverel S, Mei M, Popplewell L, Yi S, Song JY, Tao S, Wu X, Chan WC, Forman SJ, Kwak LW, Rosen ST, Newman EM. Inhibition of MDR1 overcomes resistance to Brentuximab Vedotin in Hodgkin Lymphoma. Clin Cancer Res. 2020;26(5):1034-44.

52. Nademanee A, Sureda A, Stiff P, Holowiecki J, Abidi M, Hunder N, Pecsok M, Uttarwar M, Purevjal I, Sweetenham J. Safety analysis of brentuximab vedotin from the phase III AETHERA trial in Hodgkin lymphoma in the post-transplant consolidation setting. Biol Blood Marrow Transpl. 2018;24(11):2354-9.

53. Herrera AF, Chen L, Nieto $Y$, Holmberg L, Johnston PB, Mei M, Popplewell L, Armenian SH, Cao T, Farol L, Sahebi F, Spielberger R, Chen R, Nademanee AP, Peters L, Kennedy N, Rosen ST, Kwak LW, Forman SJ, Feldman TA. Consolidation with nivolumab and brentuximab vedotin after autologous hematopoietic cell transplantation in patients with high-risk Hodgkin lymphoma. Blood. 2020;136(Suppl 1):19-20.

54. Kersten MJ, Driessen J, Zijlstra JM, Plattel WJ, Morschhauser F, Lugtenburg PJ, Brice P, Hutchings M, Gastinne T, Liu R, Burggraaff CN, Nijland M, Tonino SH, Arens AlJ, Valkema R, van Tinteren H, Lopez-Yurda M, Diepstra A, De Jong D, Hagenbeek A. Combining brentuximab vedotin with dexamethasone, high-dose cytarabine and cisplatin as salvage treatment in relapsed or refractory Hodgkin lymphoma: 
the phase II HOVON/LLPC Transplant BRaVE study. Haematologica. 2021;106(4):1129-37.

55. Broccoli A, Argnani L, Botto B, Corradini P, Pinto A, Re A, Vitolo U, Fanti $S$, Stefoni V, Zinzani PL. Fondazione Italiana Linfomi O: First salvage treatment with bendamustine and brentuximab vedotin in Hodgkin lymphoma: a phase 2 study of the Fondazione Italiana Linfomi. Blood Cancer J. 2019;9:100.

56. Moskowitz AJ, Advani RH, Bartlett NL, Vose JM, Ramchandren R, Feldman TA, LaCasce AS, Christian BA, Ansell SM, Moskowitz CH, Brown L, Taft D, Ansari S, Zak DE, Sacchi M, Manley T, Herrera AF. Brentuximab vedotin and nivolumab for relapsed or refractory classic Hodgkin lymphoma: long-term follow-up results from the single-arm phase 1/2 study. Blood. 2019;134(Suppl 1):238.

57. Straus DJ, Dlugosz-Danecka M, Alekseev S, Illes A, Picardi M, LechMaranda E, Feldman T, Smolewski P, Savage KJ, Bartlett NL, Walewski J, Ramchandren R, Zinzani PL, Hutchings M, Connors JM, Radford J, Munoz J, Kim WS, Advani R, Ansell SM, Younes A, Miao H, Liu R, Fenton K, Forero-Torres A, Gallamini A. Brentuximab vedotin with chemotherapy for stage III/IV classical Hodgkin lymphoma: 3-year update of the ECHELON-1 study. Blood. 2020;135(10):735-42.

58. Straus DJ, Dlugosz-Danecka M, Connors JM, Illes A, Picardi M, LechMaranda E, Feldman T, Smolewski P, Savage KJ, Bartlett NL, Walewski J, Ramchandren R, Zinzani PL, Hutchings M, Munoz J, Kim WS, Advani R, Ansell SM, Younes A, Gallamini A, Liu R, Little M, Fenton K, Fanale MA, Radford JA. Brentuximab vedotin with chemotherapy for patients with previously untreated, stage III/IV classical Hodgkin lymphoma: 5-year update of the ECHELON-1 study. Blood. 2020;136(Suppl 1):26-8.

59. Cheson BD, Bartlett NL, LaPlant B, Lee HJ, Advani RJ, Christian B, Diefenbach CS, Feldman TA, Ansell SM. Brentuximab vedotin plus nivolumab as first-line therapy in older or chemotherapy-ineligible patients with Hodgkin lymphoma (ACCRU): a multicentre, single-arm, phase 2 trial. Lancet Haematol. 2020;7(11):e808-15.

60. Prince HM, Kim YH, Horwitz SM, Dummer R, Scarisbrick J, Quaglino P, Zinzani PL, Wolter P, Sanches JA, Ortiz-Romero PL, Akilov OE, Geskin L, Trotman J, Taylor K, Dalle S, Weichenthal M, Walewski J, Fisher D, Dreno B, Stadler R, Feldman T, Kuzel TM, Wang Y, Palanca-Wessels MC, Zagadailov E, Trepicchio WL, Zhang W, Lin H-M, Liu Y, Huebner D, et al. Brentuximab vedotin or physician's choice in CD30-positive cutaneous T-cell lymphoma (ALCANZA): an international, open-label, randomised, phase 3, multicentre trial. Lancet. 2017;390(10094):555-66.

61. William B, Huang Y, Brammer J, Chung C. A Phase II Trial of Brentuximab vedotin (BV) and lenalidomide (Len) in relapsed and refractory $(r / r)$ cutaneous (CTCL) and peripheral (PTCL) T-cell lymphomas; preliminary results. Clin Lymphoma Myeloma Leuk. 2019;19:S359-60.

62. Horwitz S, O'Connor OA, Pro B, Illidge T, Fanale M, Advani R, Bartlett $\mathrm{NL}$, Christensen JH, Morschhauser F, Domingo-Domenech E, Rossi G, Kim WS, Feldman T, Lennard A, Belada D, Illes A, Tobinai K, Tsukasaki K, Yeh S-P, Shustov A, Huttmann A, Savage KJ, Yuen S, Iyer S, Zinzani PL, Hua Z, Little M, Rao S, Woolery J, Manley T, et al. Brentuximab vedotin with chemotherapy for CD30-positive peripheral T-cell lymphoma (ECHELON-2): a global, double-blind, randomised, phase 3 trial. Lancet. 2019;393(10168):229-40.

63. Horwitz SM, O'Connor OA, Pro B, Illidge T, Iyer SP, Advani R, Bartlett NL, Christensen JH, Morschhauser F, Domingo-Domenech E, Rossi G, Kim WS, Feldman TA, Menne T, Belada D, Illes A, Tobinai K, Tsukasaki K, Yeh S-P, Shustov AR, Huttmann A, Savage KJ, Yuen S, Zinzani PL, Miao H, Bunn V, Fenton K, Fanale MA, Puhlmann M, Truemper L. The Echelon-2 trial: 5-year results of a randomized, double-blind, phase 3 study of brentuximab Vedotin and CHP (A plus CHP) versus CHOP in Frontline Treatment of Patients with CD30-Positive Peripheral T-Cell Lymphoma. Blood. 2020;136(Suppl 1):3-5.

64. Lowe EJ, Reilly AF, Lim MS, Gross TG, Saguilig L, Barkauskas DA, Wu R, Alexander S, Bollard CM. Brentuximab vedotin in combination with chemotherapy for pediatric patients with ALK+ALCL: results of COG Trial ANHL12P1. Blood. 2021. https://doi.org/10.1182/blood.20200 09806.

65. Bartlett NL, Yasenchak CA, Sims RB, Nowakowski GS. Trial-in-progress: brentuximab vedotin in combination with lenalidomide and rituximab in subjects with relapsed or refractory diffuse large B-cell lymphoma (DLBCL). Blood. 2020;136(Suppl 1):14.
66. Salik B, Smyth MJ, Nakamura K. Targeting immune checkpoints in hematological malignancies. J Hematol Oncol. 2020;13(1):19.

67. Santoro A, Moskowitz AJ, Ferrari S, Carlo-Stella C, Fanale MA, Francis S, Sacchi M, Savage KJ. Nivolumab combined with brentuximab vedotin for relapsed/refractory mediastinal gray zone lymphoma: primary efficacy and safety analysis of the phase 2 CheckMate 436 study. Blood. 2020;136(Suppl 1):44-5.

68. Svoboda J, Bair SM, Landsburg DJ, Nasta SD, Nagle SJ, Barta SK, Khan N, Filicko-O'Hara J, Gaballa S, Strelec L, Chong E, Mitnick S, Waite TS, King C, Ballard H, Youngman M, Gerson J, Plastaras JP, Maity A, Bogusz AM, Hung SS, Nakamura H, Nejati R, Steidl C, Lim M, Ruella M, Schuster SJ. Brentuximab vedotin in combination with rituximab, cyclophosphamide, doxorubicin, and prednisone as frontline treatment for patients with CD30-positive B-cell lymphomas. Haematologica. 2020. https:// doi.org/10.3324/haematol.2019.238675.

69. Fichtner M, Dreyling M, Binder M, Trepel M. The role of B cell antigen receptors in mantle cell lymphoma. J Hematol Oncol. 2017;10(1):164.

70. Dornan D, Bennett F, Chen Y, Dennis M, Eaton D, Elkins K, French D, Go MAT, Jack A, Junutula JR, Koeppen H, Lau J, McBride J, Rawstron A, Shi X, Yu N, Yu S-F, Yue P, Zheng B, Ebens A, Polson AG. Therapeutic potential of an anti-CD79b antibody-drug conjugate, anti-CD79b-vc-MMAE, for the treatment of non-Hodgkin lymphoma. Blood. 2009;114(13):2721-9.

71. Morschhauser F, Flinn IW, Advani R, Sehn LH, Diefenbach C, Kolibaba K, Press OW, Salles G, Tilly H, Chen Al, Assouline S, Cheson BD, Dreyling M, Hagenbeek A, Zinzani PL, Jones S, Cheng J, Lu D, Penuel E, Hirata J, Wenger M, Chu Y-W, Sharman J. Polatuzumab vedotin or pinatuzumab vedotin plus rituximab in patients with relapsed or refractory non-Hodgkin lymphoma: final results from a phase 2 randomised study (ROMULUS). Lancet Haematol. 2019;6(5):E254-65.

72. Gritti G, Marlton P, Phillips TJ, Arthur C, Bannerji R, Corradini P, Johnston A, Seymour JF, Yuen S, Hirata J, Musick L, Saha S, Croft B, Flowers C. Polatuzumab vedotin plus venetoclax with rituximab in relapsed/ refractory diffuse large B-cell lymphoma: primary efficacy analysis of a phase Ib/ll study. Blood. 2020;136(Suppl 1):45-7.

73. Diefenbach C, Kahl BS, Banerjee L, McMillan AK, Miall F, Briones J, Cordoba R, Hirata J, Chang Y, Musick L, Abrisqueta P. Polatuzumab vedotin plus obinutuzumab and lenalidomide in patients with relapsed/refractory follicular lymphoma: primary analysis of the full efficacy population in a phase Ib/II trial. Blood. 2019;134(Suppl 1):126.

74. Tilly H, Morschhauser F, Bartlett NL, Mehta A, Salles G, Haioun C, Munoz J, Chen Al, Kolibaba K, Lu D, Yan M, Penuel E, Hirata J, Lee C, Sharman JP. Polatuzumab vedotin in combination with immunochemotherapy in patients with previously untreated diffuse large B-cell lymphoma: an open-label, non-randomised, phase $1 \mathrm{~b}-2$ study. Lancet Oncol. 2019;20(7):998-1010.

75. Wang K, Wei G, Liu D. CD19: a biomarker for B cell development, lymphoma diagnosis and therapy. Exp Hematol Oncol. 2012;1 (1):36-36.

76. Hamadani M, Radford J, Carlo-Stella C, Caimi PF, Reid E, O'Connor OA, Feingold JM, Ardeshna KM, Townsend W, Solh M, Heffner LT, Ungar D, Wang L, Boni J, Havenith K, Qin Y, Kahl BS. Final results of a phase 1 study of loncastuximab tesirine in relapsed/refractory B-cell non-Hodgkin lymphoma. Blood. 2021;137(19):2634-45.

77. Salles G, Duell J, Gonzalez Barca E, Tournilhac O, Jurczak W, Liberati AM, Nagy Z, Obr A, Gaidano G, Andre M, Kalakonda N, Dreyling M, Weirather J, Dirnberger-Hertweck M, Ambarkhane S, Fingerle-Rowson G, Maddocks $\mathrm{K}$. Tafasitamab plus lenalidomide in relapsed or refractory diffuse large B-cell lymphoma (L-MIND): a multicentre, prospective, single-arm, phase 2 study. Lancet Oncol. 2020;21 (7):978-88.

78. Caimi PF, Ai WZ, Alderuccio JP, Ardeshna KM, Hamadani M, Hess BT, Kahl BS, Radford JA, Solh M, Stathis A, Zinzani PL, Feingold J, Ungar D, Qin Y, He S, Carlo-Stella C. Efficacy and safety of loncastuximab tesirine (ADCT-402) in relapsed/refractory diffuse large B-cell lymphoma. Blood. 2020;136(Suppl 1):35-7.

79. Hong EE, Erickson H, Lutz RJ, Whiteman KR, Jones G, Kovtun Y, Blanc V, Lambert JM. Design of Coltuximab Ravtansine, a CD19-targeting antibody-drug conjugate (ADC) for the treatment of B-cell malignancies: structure-activity relationships and preclinical evaluation. Mol Pharm. 2015;12(6):1703-16.

80. Trněný M, Verhoef G, Dyer MJ, Ben Yehuda D, Patti C, Canales M, Lopez A, Awan FT, Montgomery PG, Janikova A, Barbui AM, Sulek K, Terol MJ, Radford J, Guidetti A, Di Nicola M, Siraudin L, Hatteville L, Schwab 
S, Oprea C, Gianni AM. A phase II multicenter study of the anti-CD19 antibody drug conjugate coltuximab ravtansine (SAR3419) in patients with relapsed or refractory diffuse large B-cell lymphoma previously treated with rituximab-based immunotherapy. Haematologica. 2018;103(8):1351-8.

81. Coiffier B, Thieblemont C, de Guibert S, Dupuis J, Ribrag V, Bouabdallah R, Morschhauser F, Navarro R, Le Gouill S, Haioun C, Houot R, Casasnovas $\mathrm{O}$, Holte H, Lamy T, Broussais F, Payrard S, Hatteville L, Tilly H. A phase II, single-arm, multicentre study of coltuximab ravtansine (SAR3419) and rituximab in patients with relapsed or refractory diffuse large B-cell lymphoma. Br J Haematol. 2016;173(5):722-30.

82. Moskowitz CH, Fanale MA, Shah BD, Advani RH, Chen R, Kim S, Kostic A, Liu TN, Peng J, Forero-Torres A. A phase 1 study of Denintuzumab Mafodotin (SGN-CD19A) in relapsed/refactory B-lineage Non-Hodgkin lymphoma. Blood. 2015;126(23):3.

83. Peng W, Paulson JC. CD22 ligands on a natural N-glycan scaffold efficiently deliver toxins to B-lymphoma cells. J Am Chem Soc. 2017;139(36):12450-8.

84. O'Reilly MK, Tian H, Paulson JC. CD22 is a recycling receptor that can shuttle cargo between the cell surface and endosomal compartments of B cells. J Immunol. 2011;186(3):1554-63.

85. DeAngelo DJ, Advani AS, Marks DI, Stelljes M, Liedtke M, Stock W, Gokbuget N, Jabbour E, Merchant A, Wang T, Vandendries E, Neuhof A, Kantarjian $\mathrm{H}$, O'Brien S. Inotuzumab ozogamicin for relapsed/refractory acute lymphoblastic leukemia: outcomes by disease burden. Blood Cancer J. 2020;10(8):11.

86. Paul MR, Wong V, Aristizabal P, Kuo DJ. Treatment of recurrent refractory pediatric Pre-B acute lymphoblastic leukemia using inotuzumab ozogamicin monotherapy resulting in CD22 antigen expression loss as a mechanism of therapy resistance. J Pediatr Hematol Oncol. 2019;41(8):E546-9.

87. Samra B, Jabbour E, Ravandi F, Kantarjian H, Short NJ. Evolving therapy of adult acute lymphoblastic leukemia: state-of-the-art treatment and future directions. J Hematol Oncol. 2020;13(1):17.

88. Fayad L, Offner F, Smith MR, Verhoef $G$, Johnson P, Kaufman JL, Rohatiner A, Advani A, Foran J, Hess G, Coiffier B, Czuczman M, Gine E, Durrant S, Kneissl M, Luu KT, Hua SY, Boni J, Vandendries E, Dang NH. Safety and clinical activity of a combination therapy comprising two antibody-based targeting agents for the treatment of non-hodgkin lymphoma: results of a phase I/II study evaluating the immunoconjugate inotuzumab ozogamicin with rituximab. J Clin Oncol. 2013;31(5):573-83.

89. Dang NH, Ogura M, Castaigne S, Fayad LE, Jerkeman M, Radford J, Pezzutto A, Bondarenko I, Stewart DA, Shnaidman M, Sullivan S, Vandendries E, Tobinai K, Ramchandren R, Hamlin PA, Gine E, Ando K. Randomized, phase 3 trial of inotuzumab ozogamicin plus rituximab versus chemotherapy plus rituximab for relapsed/refractory aggressive B-cell non-Hodgkin lymphoma. Br J Haematol. 2018;182(4):583-6.

90. Sangha R, Davies A, Dang NH, Ogura M, MacDonald DA, Ananthakrishnan R, Paccagnella ML, Vandendries E, Boni J, Goh YT. Phase 1 study of inotuzumab ozogamicin combined with R-GDP for the treatment of patients with relapsed/refractory CD22+ B-cell non-Hodgkin lymphoma. J Drug Assess. 2017;6(1):10-7.

91. Ogura M, Tobinai K, Hatake K, Davies A, Crump M, Ananthakrishnan R, Ishibashi T, Paccagnella ML, Boni J, Vandendries E, MacDonald D. Phase I study of inotuzumab ozogamicin combined with R-CVP for relapsed/ refractory CD22+B-cell non-Hodgkin lymphoma. Clin Cancer Res. 2016;22(19):4807-16.

92. Goy A, Forero A, Wagner-Johnston N, Ehmann WC, Tsai M, Hatake K, Ananthakrishnan R, Volkert A, Vandendries E, Ogura M. A phase 2 study of inotuzumab ozogamicin in patients with indolent B-cell non-Hodgkin lymphoma refractory to rituximab alone, rituximab and chemotherapy, or radioimmunotherapy. Br J Haematol. 2016;174(4):571-81.

93. Wagner-Johnston ND, Goy A, Rodriguez MA, Ehmann WC, Hamlin PA, Radford J, Thieblemont C, Suh C, Sweetenham J, Huang Y, Sullivan ST, Vandendries ER, Gisselbrecht C. A phase 2 study of inotuzumab ozogamicin and rituximab, followed by autologous stem cell transplant in patients with relapsed/refractory diffuse large B-cell lymphoma. Leuk Lymphoma. 2015;56(10):2863-9.

94. DiJoseph JF, Dougher MM, Kalyandrug LB, Armellino DC, Boghaert ER, Hamann PR, Moran JK, Damle NK. Antitumor efficacy of a combination of CMC-544 (inotuzumab ozogamicin), a CD22-targeted cytotoxic immunoconjugate of calicheamicin, and rituximab against non-Hodgkin's B-cell lymphoma. Clin Cancer Res. 2006;12(1):242-9.

95. Advani A, Coiffier B, Czuczman MS, Dreyling M, Foran J, Gine E, Gisselbrecht C, Ketterer N, Nasta S, Rohatiner A, Schmidt-Wolf IGH, Schuler M, Sierra J, Smith MR, Verhoef G, Winter JN, Boni J, Vandendries E, Shapiro M, Fayad L. Safety, pharmacokinetics, and preliminary clinical activity of inotuzumab ozogamicin, a novel immunoconjugate for the treatment of B-cell non-Hodgkin's Lymphoma: results of a phase I study. J Clin Oncol. 2010;28(12):2085-93.

96. Advani RH, Lebovic D, Chen A, Brunvand M, Goy A, Chang JE, Hochberg E, Yalamanchili S, Kahn R, Lu D, Agarwal P, Dere RC, Hsieh HJ, Jones S, Chu YW, Cheson BD. Phase I study of the anti-CD22 antibody-drug conjugate Pinatuzumab Vedotin with/without Rituximab in patients with relapsed/refractory B-cell non-Hodgkin lymphoma. Clin Cancer Res. 2017;23(5):1167-76.

97. Hernandez-Ilizaliturri FJ, Flinn IW, Kuruvilla J, Assouline SE, Ulrickson ML, Christian BA, Landsburg DJ, Stuart M, Lowman H, Levin N. A Phase I pharmacokinetic (PK) and safety study of Trph-222 in patients with relapsed/refractory B-cell non-Hodgkin lymphoma (R/R NHL): doseescalation results. Blood. 2020;136(Suppl 1):41-2.

98. Drake PM, Carlson A, McFarland JM, Banas S, Barfield RM, Zmolek W, Kim YC, Huang BCB, Kudirka R, Rabuka D. CAT-02-106, a Site-specifically conjugated anti-CD22 antibody bearing an MDR1-resistant Maytansine payload yields excellent efficacy and safety in preclinical models. Mol Cancer Ther. 2018;17(1):161-8.

99. Wang $L$, Li LR, Young KH. New agents and regimens for diffuse large $B$ cell lymphoma. J Hematol Oncol. 2020;13(1):23.

100. Fanale MA, Hamlin PA, Park SI, Persky DO, Higgins JP, Burnett C, Dabovic K, Poma E, Sarapa N, Younes A. Safety and efficacy of anti-CD20 immunotoxin MT-3724 in relapsed/refractory (R/R) B-cell non-Hodgkin lymphoma (NHL) in a phase I study. J Clin Oncol. 2018;36(15_suppl):7580.

101. Burnett C, Gordon G, Strack T, Lehner T, Higgins JP, Tache J. A Phase 2a Open-label study to investigate safety and tolerability (including the MTD), efficacy, pharmacokinetics, pharmacodynamics and immunogenicity of MT-3724 in combination with lenalidomide in subjects with relapsed or refractory B-cell non-Hodgkin lymphoma. Blood. 2019;134(Suppl 1):1597.

102. Flynn MJ, Hartley JA. The emerging role of anti-CD25 directed therapies as both immune modulators and targeted agents in cancer. $\mathrm{Br} \mathrm{J}$ Haematol. 2017;179(1):20-35.

103. Yang Z-Z, Grote DM, Ziesmer SC, Manske MK, Witzig TE, Novak AJ, Ansell SM. Soluble IL-2R alpha facilitates IL-2-mediated immune responses and predicts reduced survival in follicular B-cell non-Hodgkin lymphoma. Blood. 2011;118(10):2809-20.

104. Yamauchi T, Matsuda Y, Takai M, Tasaki T, Tai K, Hosono N, Negoro E, Ikegaya S, Takagi K, Kishi S, Yoshida A, Urasaki Y, Iwasaki H, Ueda T. Early relapse is associated with high serum soluble Interleukin-2 receptor after the sixth cycle of $\mathrm{R}-\mathrm{CHOP}$ chemotherapy in patients with advanced diffuse large B-Cell lymphoma. Anticancer Res. 2012;32(11):5051-7.

105. Kadin ME, Pavlov IY, Delgado JC, Vonderheid EC. High soluble CD30, CD25, and IL-6 may identify patients with worse survival in CD30+ cutaneous lymphomas and early mycosis fungoides. J Investig Dermatol. 2012;132(3):703-10.

106. Yun $X Y$, Zhang $Y$, Wang $X$. Recent progress of prognostic biomarkers and risk scoring systems in chronic lymphocytic leukemia. Biomark Res. 2020;8(1):11.

107. Izykowska K, Rassek K, Korsak D, Przybylski GK. Novel targeted therapies of T cell lymphomas. J Hematol Oncol. 2020;13(1):38.

108. Collins GP, Horwitz SM, Davies A, Karnad A, Samaniego F, Spira Al, Fields PA, Menne T, Boni J, Cruz H, Feingold J, He S, Wuerthner J, Hamadani M. Adct-301 (Camidanlumab Tesirine), a novel pyrrolobenzodiazebased CD25-targeting antibody drug conjugate, in a phase 1 study of replased/refractory non-Hodgkin lymphoma shows activity in T-cell lymphoma. Blood. 2018;132(Suppl 1):1658.

109. Hamadani M, Collins GP, Samaniego F, Spira Al, Davies A, Radford J, Caimi P, Menne T, Boni J, Cruz H, Feingold J, He S, Wuerthner J, Horwitz SM. Phase 1 study of Adct-301 (Camidanlumab Tesirine), a novel pyrrolobenzodiazepine-based antibody drug conjugate, in relapsed/ refractory classical Hodgkin lymphoma. Blood. 2018;132(Suppl 1):928. 
110. Wang R, Li L, Zhang S, Li Y, Wang X, Miao Q, Zhen Y. A novel enediyneintegrated antibody-drug conjugate shows promising antitumor efficacy against CD30+ lymphomas. Mol Oncol. 2018;12(3):339-55.

111. Xu-Monette ZY, Li L, Byrd JC, Jabbar KJ, Manyam GC, de Winde CM, van den Brand M, Tzankov A, Visco C, Wang J, Dybkaer K, Chiu A, Orazi A, Zu Y, Bhagat G, Richards KL, Hsi ED, Choi WWL, Huh J, Ponzoni M, Ferreri AJM, Moller MB, Parsons BM, Winter JN, Wang M, Hagemeister FB, Piris MA, van Krieken JH, Medeiros LJ, Li Y et al. Assessment of CD37 B-cell antigen and cell of origin significantly improves risk prediction in diffuse large B-cell lymphoma. Blood. 2016;128(26):3083-100.

112. Deckert J, Park PU, Chicklas S, Yi Y, Li M, Lai KC, Mayo MF, Carrigan CN, Erickson HK, Pinkas J, Lutz RJ, Chittenden T, Lambert JM. A novel antiCD37 antibody-drug conjugate with multiple anti-tumor mechanisms for the treatment of B-cell malignancies. Blood. 2013;122(20):3500-10.

113. Stathis A, Flinn IW, Madan S, Maddocks K, Freedman A, Weitman S, Zucca E, Munteanu MC, Lia Palomba M. Safety, tolerability, and preliminary activity of IMGN529, a CD37-targeted antibody-drug conjugate, in patients with relapsed or refractory B-cell non-Hodgkin lymphoma: a dose-escalation, phase I study. Invest New Drugs. 2018;36(5):869-76.

114. Hicks SW, Lai KC, Gavrilescu LC, Yi Y, Sikka S, Shah P, Kelly ME, Lee J, Lanieri L, Ponte JF, Sloss CM, Romanelli A. The Antitumor activity of IMGN529, a CD37-targeting antibody-drug conjugate, is potentiated by rituximab in non-Hodgkin lymphoma models. Neoplasia. 2017;19(9):661-71.

115. Pereira DS, Guevara Cl, Jin L, Mbong N, Verlinsky A, Hsu SJ, Aviña H, Karki S, Abad JD, Yang P, Moon SJ, Malik F, Choi MY, An Z, Morrison K, ChallitaEid PM, Doñate F, Joseph IB, Kipps TJ, Dick JE, Stover DR. AGS67E, an anti-CD37 monomethyl Auristatin E antibody-drug conjugate as a potential therapeutic for $\mathrm{B} / \mathrm{T}$-cell malignancies and $\mathrm{AML}$ : a new role for CD37 in AML. Mol Cancer Ther. 2015;14(7):1650-60.

116. Sawas A, Savage KJ, Perez R, Advani RH, Butturini A, Lackey J, Trave F, Anand B, Huang Y, Reyno L, O'Connor OA. A phase 1 study of the anti-CD37 antibody-drug conjugate AGS67E in advanced lymphoid malignancies. Interim results. Blood. 2015;126(23):3976.

117. Sawas A, Savage KJ, Perez RP, Advani RH, Melhem-Bertrandt A, Lackey J, Trave F, Anand B, Huang Y, Vincent M, Reyno LM, O'Connor OA. A first in human experience of the anti-CD37 antibody-drug conjugate AGS67E in lymphoid malignancies. J Clin Oncol. 2016;34(15_suppl):7549.

118. Karki S, Avina H, Lackey J, Sawas A, Savage KJ, Perez R, Advani R, Zain J, O'Connor OA, Gulesserian S, Zhao H, Yang P, Morrison K, Reyno L, Donate F. Evaluation of CD37 expression and binding of AGS67E, an antibody-drug conjugate (ADC) against CD37, on white blood cells (WBCs) collected from phase I non-Hodgkin lymphoma (NHL) patients. Can Res. 2017;77(Suppl 13):2709.

119. Bertrand $P$, Maingonnat $C$, Penther $D$, Guney S, Ruminy P, Picquenot JM, Mareschal S, Alcantara M, Bouzelfen A, Dubois S, Figeac M, Bastard $\mathrm{C}$, Tilly $\mathrm{H}$, Jardin F. The costimulatory molecule CD70 is regulated by distinct molecular mechanisms and is associated with overall survival in diffuse large B-cell lymphoma. Genes Chromosom Cancer. 2013;52(8):764-74.

120. Yoshino K, Kishibe K, Nagato T, Ueda S, Komabayashi Y, Takahara M, Harabuchi Y. Expression of CD70 in nasal natural killer/T cell lymphoma cell lines and patients; its role for cell proliferation through binding to soluble CD27. Br J Haematol. 2013;160(3):331-42.

121. Phillips T, Barr PM, Park SI, Kolibaba K, Caimi PF, Chhabra S, Kingsley EC, Boyd T, Chen R, Carret A-S, Gartner EM, Li H, Yu C, Smith DC. A phase 1 trial of SGN-CD70A in patients with CD70-positive diffuse large B cell lymphoma and mantle cell lymphoma. Invest New Drugs. 2019;37(2):297-306

122. Owonikoko TK, Hussain A, Stadler WM, Smith DC, Kluger H, Molina AM, Gulati P, Shah A, Ahlers CM, Cardarelli PM, Cohen LJ. First-in-human multicenter phase I study of BMS-936561 (MDX-1203), an antibodydrug conjugate targeting CD70. Cancer Chemother Pharmacol. 2016;77(1):155-62.

123. Tannir NM, Forero-Torres A, Ramchandren R, Pal SK, Ansell SM, Infante JR, de Vos S, Hamlin PA, Kim SK, Whiting NC, Gartner EM, Zhao B, Thompson JA. Phase I dose-escalation study of SGN-75 in patients with CD70-positive relapsed/refractory non-Hodgkin lymphoma or metastatic renal cell carcinoma. Invest New Drugs. 2014;32(6):1246-57.

124. Zhao S, Molina A, Yu A, Hanson J, Cheung H, Li X, Natkunam Y. High frequency of CD74 expression in lymphomas: implications for targeted therapy using a novel anti-CD74-drug conjugate. J Pathol Clin Res. 2019;5(1):12-24.

125. Shah NN, Mattour AH, Popplewell LL, Andreadis C, Melear JM, Spira Al, Shulman J, Manda S, Burke JM, Chhabra S, Sharman JP, Krishnan A, Shah N, Dilea C, Kuriakose J, Berman CJ, Matheny SL, Leonard JP, Molina A. Preliminary results of an ongoing phase 1 dose escalation study of the novel anti-CD74 antibody drug conjugate (ADC), STRO-001. Patients with B-Cell Non-Hodgkin Lymphoma. Blood. 2020;136(Suppl 1):29-30.

126. Phase I/II Study of hLL1-DOX in Relapsed NHL and CLL https://clinicaltr ials.gov/ct2/show/NCT01585688. Accessed 21 Nov 2020.

127. Li X, Abrahams C, Embry M, Yu A, Kahana J, Brown M, Narla RK, Barnes L, Schwartz E, Boylan J, Zawada J, Stephenson H, Bruhns M, Bussell S, Steiner A, Galan A, Kline T, Yam A, Stafford R, Hoffmann H, Matheny S, DeAlmeida V, Vasquez N, Heinsohn H, Sato A, Molina A, Hallam T, Lupher M Jr. Targeting CD74 with novel antibody drug conjugates (ADCs) for the treatment of B-cell non-Hodgkin's lymphoma (NHL). Blood. 2016;128(22):464.

128. Herrera AF, Patel MR, Burke JM, Advani RH, Cheson BD, Sharman JP, Penuel E, Polson AG, Leng N, Li C, Schuth E, Vaze A, Samineni D, Elstrom $R$, Diefenbach CS. A phase I study of the anti-CD79b THIOMAB (TM)drug conjugate DCDS0780A in patients (pts) with relapsed or refractory B-cell non-Hodgkin's lymphoma (B-NHL). Blood. 2017;130(Suppl 1):4129.

129. Ghaderi A, Daneshmanesh AH, Moshfegh A, Kokhaei P, Vagberg J, Schultz J, Olin T, Harrysson S, Smedby KE, Drakos E, Rassidakis GZ, Osterborg A, Mellstedt H, Hojjat-Farsangi M. ROR1 is expressed in diffuse large B-cell lymphoma (DLBCL) and a small molecule inhibitor of ROR1 (KAN0441571C) induced apoptosis of lymphoma cells. Biomedicines. 2020;8(6):15.

130. Vaisitti T, Jessen K, Vo T-T, Ko M, Arruga F, Vitale N, Braggio E, Di Napoli A, Chadburn A, Allan JN, Furman RR, Miller LL, Lanutti BJ, Deaglio S. VIs-101 is a novel therapeutic antibody-drug conjugate (ADC) targeting receptor tyrosine kinase-like orphan receptor 1 (ROR1) in Richter's syndrome (RS). Blood. 2019;134(Suppl 1):2856.

131. Wang M, Barrientos JC, Furman RR, Mei M, Barr PM, Choi MY, de Vos S, Kallam A, Patel K, Rule S, Flanders K, Jessen KA, Riebling PC, Graham P, King L, Schmidt EM, Lannutti BJ, Johnson DM, Miller LL, Spurgeon SE. VLS-101, a ROR1-targeting antibody-drug conjugate, demonstrates a predictable safety profile and clinical efficacy in patients with heavily pretreated mantle cell lymphoma and diffuse large B-cell lymphoma. Blood. 2020;136(Suppl 1):13-4.

132. Hou J-Z, Ye JC, Pu JJ, Liu H, Ding W, Zheng H, Liu D. Novel agents and regimens for hematological malignancies: recent updates from 2020 ASH annual meeting. J Hematol Oncol. 2021;14(1):66.

133. Mian YA, Widhopf GF II, Thanh-Trang V, Jessen K, Rassenti LZ, Kipps TJ. Development of cirmtuzumab antibody-drug conjugates (ADCs) targeting receptor tyrosine kinase-like orphan receptor 1 (ROR1). Blood. 2018;132(Suppl 1):1862.

134. Karvonen $\mathrm{H}$, Chiron D, Niininen W, Ek S, Jerkeman M, Moradi E, Nykter M, Heckman CA, Kallioniemi O, Murumagi A, Ungureanu D. Crosstalk between ROR 1 and BCR pathways defines novel treatment strategies in mantle cell lymphoma. Blood Adv. 2017;1(24):2257-68.

135. Yi M, Niu MK, Xu LP, Luo SX, Wu KM. Regulation of PD-L1 expression in the tumor microenvironment. J Hematol Oncol. 2021;14(1):13.

136. Akinleye A, Rasool Z. Immune checkpoint inhibitors of PD-L1 as cancer therapeutics. J Hematol Oncol. 2019;12(1):13.

137. Gao SB, Wang SC, Song YP. Novel immunomodulatory drugs and neosubstrates. Biomark Res. 2020;8(1):8.

138. Wang Y, Nowakowski GS, Wang ML, Ansell SM. Advances in CD30-and PD-1-targeted therapies for classical Hodgkin lymphoma. J Hematol Oncol. 2018;11:57.

139. Kozako T, Aikawa A, Ohsugi T, Uchida Y, Kato N, Sato K, Ishitsuka K, Yoshimitsu M, Honda S. High expression of NAMPT in adult T-cell leukemia/lymphoma and anti-tumor activity of a NAMPT inhibitor. Eur J Pharmacol. 2019;865:9.

140. Ng G, Spreter T, Davies R, Wickman G. ZW38, a novel Azymetric bispecific CD19-directed CD3 T cell engager antibody drug conjugate with controlled T cell activation and improved B Cell cytotoxicity. Blood. 2016;128(22):1841.

141. Junutula JR, Raab H, Clark S, Bhakta S, Leipold DD, Weir S, Chen Y, Simpson M, Tsai SP, Dennis MS, Lu Y, Meng YG, Ng C, Yang J, Lee CC, 
Duenas E, Gorrell J, Katta V, Kim A, McDorman K, Flagella K, Venook $R$, Ross S, Spencer SD, Wong WL, Lowman HB, Vandlen R, Sliwkowski MX, Scheller RH, Polakis P, et al. Site-specific conjugation of a cytotoxic drug to an antibody improves the therapeutic index. Nat Biotechnol. 2008;26(8):925-32.

142. Sadowsky JD, Pillow TH, Chen JH, Fan F, He CR, Wang YL, Yan G, Yao H, Xu ZJ, Martin S, Zhang DL, Chu P, delaCruz-Chuh J, O'Donohue A, Li GM, Del Rosario G, He JT, Liu LN, Ng C, Su DA, Phillips GDL, Kozak KR, Yu SF, Xu KY, Leipold D, Wai J. Development of efficient chemistry to generate site-specific disulfide-linked protein- and peptide-payload conjugates: application to THIOMAB antibody-drug conjugates. Bioconjugate Chem. 2017;28(8):2086-98.

143. Ohri RV, Bhakta S, Raab H, Vandlen R, Junutul J, Erickson H. A highthroughput conjugation strategy for the selection of THIOMAB (TM) antibodies with desired properties for antibody-drug conjugation. Can Res. 2015;75(Suppl 15):650.

144. Dondapati SK, Stech M, Zemella A, Kubick S. Cell-free protein synthesis: a promising option for future drug development. BioDrugs. 2020;34(3):327-48.

145. Le Gall CM, van der Schoot JMS, Ramos-Tomillero I, Khalily MP, van Dalen FJ, Wijfjes Z, Smeding L, van Dalen D, Cammarata A, Bonger KM, Figdor CG, Scheeren FA, Verdoes M. Dual site-specific chemoenzymatic antibody fragment conjugation using CRISPR-based hybridoma engineering. Bioconjug Chem. 2021;32(2):301-10.

146. Hochberg J, Alexander S: Resistance to antibody-drug conjugate. In: Resistance to targeted therapies in lymphomas. edited by Xavier AC, Cairo MS, vol. 21, pp. 57-69 (2019).

147. Corbett S, Huang S, Zammarchi F, Howard PW, van Berkel PH, Hartley JA. The role of specific ATP-binding cassette transporters in the acquired resistance to pyrrolobenzodiazepine dimer-containing antibody-drug conjugates. Mol Cancer Ther. 2020;19(9):1856-65.

148. Dai Z, Gu XY, Xiang SY, Gong DD, Man CF, Fan Y. Research and application of single-cell sequencing in tumor heterogeneity and drug resistance of circulating tumor cells. Biomark Res. 2020;8(1):8.

149. Zhou XX, Zhan LQ, Huang $K$, Wang $X$. The functions and clinical significance of circRNAs in hematological malignancies. J Hematol Oncol. 2020;13(1):15

150. Hicks SW, Tarantelli C, Wilhem A, Gaudio E, Li M, Arribas AJ, Spriano F, Bordone R, Cascione L, Lai KC, Qiu Q, Taborelli M, Rossi D, Stussi G, Zucca
E, Stathis A, Sloss CM, Bertoni F. The novel CD19-targeting antibodydrug conjugate huB4-DGN462 shows improved anti-tumor activity compared to SAR3419 in CD19-positive lymphoma and leukemia models. Haematologica. 2019;104(8):1633-9.

151. Li Z, Wang M, Yao X, Li H, Li S, Liu L, Yu D, Li X, Fang J, Huang C. Development of novel anti-CD19 antibody-drug conjugates for B-cell lymphoma treatment. Int Immunopharmacol. 2018;62:299-308.

152. Li L, Tong W, Lau M, Fells K, Zhu T, Sun Y, Kovacs E, Khasanov A, Yan Z, Deng D, Takeshita K, Kaufmann GF, Ji H, Li H, Zhang H. Preclinical development of an anti-CD38 antibody-drug conjugate for treatment of hematological malignancies. Blood. 2019;134(Suppl 1):5621.

153. Kirchhoff D, Stelte-Ludwig B, Lerchen HG, Wengner AM, von Ahsen O, Buchmann P, Marsch S, Mahlert C, Greven S, Dietz L, Erkelenz M, Zierz R, Johanssen S, Mumberg D, Sommer A. IL3RA-targeting antibody-drug conjugate BAY-943 with a kinesin spindle protein inhibitor payload shows efficacy in preclinical models of hematologic malignancies. Cancers. 2020;12(11):17.

154. Johannes S, Hammer S, Maersch S, Lerchen HG, Stelte-Ludwig B, Joerissen H, von Ahsen O, Schatz C, Greven S, Mahlert C, Mumberg D, Lejeune P. Preclinical characterization of BAY-924, a first in class ADC targeting CXCR5-positive B-cell malignancies, with a KSP inhibitor as novel payload. Can Res. 2019;79(13):2.

155. Gaudio E, Tarantelli C, Spriano F, Guidetti F, Sartori G, Bordone R, Arribas AJ, Cascione L, Bigioni M, Merlino G, Fiascarelli A, Bressan A, Mensah AA, Golino G, Lucchini R, Bernasconi E, Rossi D, Zucca E, Stussi G, Stathis A, Boyd RS, Dusek RL, Bisht A, Attanasio N, Rohlff C, Pellacani A, Binaschi M, Bertoni F. Targeting CD205 with the antibody drug conjugate MEN1309/OBT076 is an active new therapeutic strategy in lymphoma models. Haematologica. 2020;105(11):2584-91.

156. Cardillo TM, Govindan SV, Zalath MB, Rossi DL, Wang Y, Chang C-H, Goldenberg DM. IMMU-140, a novel SN-38 antibody-drug conjugate targeting HLA-DR, mediates dual cytotoxic effects in hematologic cancers and malignant melanoma. Mol Cancer Ther. 2018;17(1):150-60.

\section{Publisher's Note}

Springer Nature remains neutral with regard to jurisdictional claims in published maps and institutional affiliations.
Ready to submit your research? Choose BMC and benefit from:

- fast, convenient online submission

- thorough peer review by experienced researchers in your field

- rapid publication on acceptance

- support for research data, including large and complex data types

- gold Open Access which fosters wider collaboration and increased citations

- maximum visibility for your research: over $100 \mathrm{M}$ website views per year

At BMC, research is always in progress.

Learn more biomedcentral.com/submissions 